\title{
The Role of Xenobiotic Transporters in Ophthalmic Drug Delivery
}

\author{
Nagendra V. Chemuturi ${ }^{1}$ and Jaime A. Yáñez ${ }^{1}$ \\ Ocular Pharmacokinetics and Disposition, Alcon Research, Ltd., a Novartis Company, 6201 South Freeway, Fort Worth, \\ TX 76134-2099, USA
}

Received, August 24, 2013; Accepted, November 21, 2013; Published, December 3, 2013

\begin{abstract}
The eye is a very complex sensory organ consisting of numerous structures to coordinate the function of sight. It has a series of physical and chemical barriers to help maintain its homeostasis, and mediate environmental exposures. Transporters in the eye play a very important role in maintaining homeostasis by facilitating the movement of ions, nutrients and xenobiotics to various tissues in the eye, especially to nonvascular tissues like the lens and cornea. They also ensure proper cell signaling by shuttling neurotransmitters within the retina. Thus, they are expected to play an important role in determining the ocular exposure of drugs and other pharmacotherapeutics. However, the role of ocular transporters in ophthalmic drug delivery and their clinical relevance has not been well characterized. The purpose of the present review is to summarize the current evidence in the literature on ocular drug transporters and their role in ocular drug delivery, with the emphasis predominantly on their role in ocular pharmacokinetics.
\end{abstract}

This article is open to POST-PUBLICATION REVIEW. Registered readers (see "For Readers") may comment by clicking on ABSTRACT on the issue's contents page.

\section{INTRODUCTION}

The role of drug transporters in the gastrointestinal (GI) tract, lymphatic system, blood brain barrier (BBB), liver and kidneys is well known and documented [1-6]. Transporters can affect multiple aspects of drug disposition and can result in potential drug-drug interactions, lack of efficacy, toxicity and drug related adverse events relative to exposure levels.

Drug transporters have the potential to alter the efficacy of a molecule at the site of action, for example, in the liver or the brain [1]. The brain parenchymal cells contain transporters including Pglycoprotein (P-gp), which can efflux drugs, thus lowering their concentration at the site of action and ultimately decreasing their efficacy [2-5]. Conversely, facilitative transporters like organic cation transporters (OCTs) or dopamine transporter (DAT) would improve drug efficacy by transporting the molecule into or out of neurons, thus, increasing their target site concentration [5-7]. Although topical ocular administration is the primary method for delivery of therapeutics to the eye, not much is understood about the clinical relevance of transporters in ocular drug disposition. The eye, being responsible for the sense of vision, has evolved into an organ with complex anatomy and physiology to maintain homeostasis and ensure effective functioning. The mechanisms include transporters, ion channels, and physical barriers which act as defense mechanisms and help maintain concentrations of essentials nutrients. While there are good reviews on ocular drug transporters, little is known about their role in ocular drug efficacy, ocular pharmacokinetics and ocular safety issues [8-10]. In the present article, we review the current evidence in the literature on ocular drug transporters and their role in ocular drug delivery, with the emphasis predominantly on their role in ocular pharmacokinetics. We will also discuss their future relevance and the need to better understand their role in ocular drug delivery.

\section{ANATOMY OF THE EYE}

The eye is a very complex structure that is closely connected to the rest of the body through its

Correspondence Author: Dr. Nagendra V. Chemuturi, Ocular Pharmacokinetics and Disposition, Alcon Research, Ltd., a Novartis Company, 6201 South Freeway, Mail Stop: R3-26, Fort Worth, TX 76134-2099 USA.

Email: Nagendra.Chemuturi@,Alcon.com

\footnotetext{
${ }^{1}$ The authors contributed equally for the writing and editing of this manuscript.
} 
vascular and neural networks $[11,12]$. Its unique anatomy and physiology place several constraints on the delivery of drugs to the eye because of its innate nature to protect itself and, ultimately, the vision from exogenous substances [11]. Therefore, it is critical to understand the anatomy and physiology of the eye to design adequate and effective drug delivery systems. The objective of this review is not to cover in detail the anatomy of the eye since there are excellent reviews and articles that cover this topic in detail. We recommend the reader review these references for further detail [11, 13-33]. Ocular drug disposition is not only influenced by the complex anatomy, but also by lacrimation, tear film dilution and tear turnover mechanisms [34]. The presence of melanin and ocular transporters, as well as the blood-aqueous barrier (BAB) and blood-retinal barrier (BRB) significantly affect ocular drug disposition $[12,35-$ 39] [40-45].

There are several routes of ocular drug delivery (Table 1). The benefits and challenges of

Table 1. Summary of Route of Administration, Benefits, and Challenges in Ocular Delivery (modified from Gaudana et al. [12] with permission).

\begin{tabular}{|c|c|c|c|}
\hline Route & Benefits & Challenges & $\begin{array}{l}\text { Application in the } \\
\text { treatment of diseases }\end{array}$ \\
\hline Oral/Systemic & $\begin{array}{l}\text { Patient compliant and noninvasive } \\
\text { route of administration }\end{array}$ & $\begin{array}{l}\text { BAB, BRD, high dosing } \\
\text { causes toxicity, BA }<2 \%\end{array}$ & $\begin{array}{l}\text { Scleritis, episcleritis, } \\
\text { CMV retinitis, PU }\end{array}$ \\
\hline Topical & $\begin{array}{l}\text { High patient compliance, self- } \\
\text { administrable and noninvasive }\end{array}$ & $\begin{array}{l}\text { Higher tear dilution and } \\
\text { turnover rate, cornea acts } \\
\text { as barrier, efflux pumps, } \\
\text { BA }<5 \%\end{array}$ & $\begin{array}{l}\text { Keratitis, uveitis, } \\
\text { conjunctivitis, } \\
\text { scleritis, episcleretis, } \\
\text { blepharitis }\end{array}$ \\
\hline Intravitreal & $\begin{array}{l}\text { Direct delivery to the vitreous and } \\
\text { retina, sustains drug levels, evades } \\
\text { BRB }\end{array}$ & $\begin{array}{l}\text { Retinal detachment, } \\
\text { hemorrhage, cataract, } \\
\text { endophthalmitis, patient } \\
\text { incompliance }\end{array}$ & $\begin{array}{l}\text { AMD, PU, BRVO, } \\
\text { CRVO, DME, CME, } \\
\text { UME, CMV retinitis }\end{array}$ \\
\hline Intracameral & $\begin{array}{l}\text { Provides higher drug levels in the } \\
\text { anterior chamber, eliminates usage of } \\
\text { topical drops, reduces corneal and } \\
\text { systemic side effects seen with topical } \\
\text { steroid therapy }\end{array}$ & $\begin{array}{l}\text { Toxic anterior segment } \\
\text { syndrome (TASS) and } \\
\text { toxic endothelial cell } \\
\text { destruction syndrome } \\
\text { (TECDS) }\end{array}$ & $\begin{array}{l}\text { Anesthesia, prevention } \\
\text { of endophthalmitis, } \\
\text { inflammation and } \\
\text { pupil dilation }\end{array}$ \\
\hline Subconjunctival & $\begin{array}{l}\text { Delivery to anterior and posterior } \\
\text { segment, site for depot formulations }\end{array}$ & $\begin{array}{l}\text { Conjunctival and } \\
\text { choroidal circulation }\end{array}$ & $\begin{array}{l}\text { Glaucoma, CMV } \\
\text { retinitis, AMD, PU }\end{array}$ \\
\hline Subtenon & $\begin{array}{l}\text { High vitreal drug levels, relatively } \\
\text { nonivasive, fewer complications } \\
\text { unlike intravitreal delivery }\end{array}$ & $\begin{array}{l}\text { RPE, chemosis, } \\
\text { subconjunctival } \\
\text { hemorrhage }\end{array}$ & $\begin{array}{l}\text { DME, AMD, RVO, } \\
\text { uveitis }\end{array}$ \\
\hline Retrobulbar & $\begin{array}{l}\text { Administer high local doses like } \\
\text { anesthetics, more effective than } \\
\text { peribulbar, minimal influence on IOP }\end{array}$ & $\begin{array}{l}\text { Retrobulbar hemorrhage, } \\
\text { globe perforation, } \\
\text { respiratory arrest }\end{array}$ & Anesthesia \\
\hline $\begin{array}{l}\text { Posterior } \\
\text { juxtascleral }\end{array}$ & $\begin{array}{l}\text { Safe for delivery of depot } \\
\text { formulations, sustain drug levels up to } \\
6 \text { months to the macula, avoids risk of } \\
\text { endophthalmitis and intraocular } \\
\text { damage }\end{array}$ & $\begin{array}{l}\text { Requires surgery and } \\
\text { RPE acts as barrier }\end{array}$ & AMD \\
\hline
\end{tabular}

BA bioavailability, BAB blood-aqueous barrier, BRB blood-retinal barrier, AMD age-related macular degeneration, DME diabetic macular edema, BRVO branched retinal vein occlusion, CRVO central retinal vein occlusion, RVO retinal vein occlusion, CME cystoid macular edema, UME uveitic macular edema, CMV cytomegalovirus, IOP intraocular pressure, TASS toxic anterior segment syndrome, TECDS toxic endothelial cell destruction syndrome, RPE retinal pigmented epithelium, PU posterior uveitis 
the various routes of administration [12] as well as the complexity of ocular pharmacokinetics [46] have been reviewed elsewhere. Briefly, topical ocular administration is generally the preferable route for patients based on ease of administration and can be used for the treatment of a variety of ocular diseases. However, invasive techniques (i.e. intravitreal or intracameral injections) need to be employed for diseases such as age-related macular degeneration (AMD), retinal vein occlusion, or macular edema.

\section{TRANSPORTERS AND THEIR ROLE IN FUNCTIONING OF THE EYE}

The eye is an important sensory organ and is one of the very few which come in direct contact with the environment. One can therefore appreciate the role of transporters as a defense mechanism preventing the entry of foreign and/or possibly toxic xenobiotics into the eye, which could disrupt vision [8-10]. To date transporters in the eye and their role in ophthalmic drug delivery have not been well characterized.

In addition to serving as a defensive mechanism, transporters also help maintain $\mathrm{pH}$, ionic and osmotic equilibrium in the eye [47-50]. Membrane transporters regulate the levels of ions, glucose and vitamins to maintain homeostasis in the eye [51]. A disruption of these mechanisms leads to various conditions including cataract [51]. In a similar fashion, inhibition and activation of transporters in various matrices of the eye could lead to safety issues. For example, inhibition of the glucose transporter, found in the lens and the conjunctiva could lead to disruption of the homeostasis of the lens [51].

Cellular transporters play an important role in the disposition of drugs at the site of therapeutic action. An efflux transporter could limit the amount of drug reaching the target ocular tissue limiting their efficacy, while an uptake transporter could result in elevated levels of a drug in a particular tissue. Ophthalmic drug transporters have been the subject of investigation and the published literature indicates that they play a role in ophthalmic drug delivery. In the following sections we present information on ocular transporters known to be expressed in the eye, dividing them into anterior and posterior segments. A brief review is provided, of in vitro and in vivo techniques used to study transporters and evidence of the role of ocular transporters.

\section{Current Technologies to Study Ocular Drug Transporters}

\section{In vitro Methodologies}

A variety of in vitro techniques have been employed to investigate the expression, localization and function of transporters. Techniques like PCR, Western blotting and immunohistochemistry are used to study the expression of transporters and their localization in various tissues [52, 53]. To determine their functionality, current technologies on transporters utilize either inhibition or substrate transport studies (done as a monolayer or in suspension). Transport studies with compounds in transfected cell lines, vesicles from insects, transporter cDNA expressing insect membranes and oocytes are used to identify the substrate nature of compounds and to determine their kinetics [54-57]. Inhibition studies can also be conducted using the afore mentioned techniques. These studies reveal the substrate or inhibitor nature of a compound, as well as the nature of inhibition (competitive against non-competitive).

Corneal cell lines from humans and animal species [49, 52, 53, 58-63], are available to study drug permeability and drug transporters. The role of transporters in conjunctival cell lines like $\mathrm{HCjE}$ (human conjunctival epithelial cells), CJVE (rabbit conjunctival epithelial cells) has also been demonstrated $[58,59,64]$. The studies with HCLE (human cornea limbal epithelial cells) and $\mathrm{HCjE}$ cells were the first to show the expression of OCTN1 and OCTN2 in these cell lines and demonstrated the role of OCTN2 in the active transport of L-carnitine transport. The studies with CJVE cell line demonstrated the function of novel sodium dependent and sodium independent transport mechanisms for synthetic and endogenous opioids. The permeability of compounds across retinal cell lines like ARPE-19 and retinoblastoma cells $[65,66]$ has also been investigated. The study revealed the presence and expression of a new oligopeptide transporter (SOPT2), which transported synthetic opioid (DADLE) with partial sodium dependence. Such in vitro systems become useful to determine the permeability of compounds and the role of transporters across these barriers. The use of in vitro studies to characterize the 
capacity of a compound to act as a substrate or inhibitor of a particular transporter provides information about its ability to reach the intended site of action. Furthermore, these studies provide understanding about the kinetics of the process, the possible interactions and the potential clinical relevance.

\section{In vivo and $E x$ vivo Methodologies}

Both in vivo and ex vivo methodologies are also used to study transporters. Inhibition and saturability studies are done with wild type animals to determine in vivo kinetics of transporters. Drugdrug interaction potential can also be tested using transporter knock-out or transgenic animals [67-71], which are deficient in a particular transporter compared to the wild type animal. Studying the pharmacokinetics of the compound in the two models simultaneously gives a measure of the contribution of the transporter to the maximal concentration $\left(\mathrm{C}_{\max }\right)$ and area under the concentration-time curve (AUC) of the compound. In vivo studies to investigate the role of ocular transporters have been conducted in rabbits [72]. The role of P-gp was well demonstrated by investigating the pharmacokinetics of quinidine and erythromycin in rabbits $[72,73]$. The role of MRP5 in rabbits was also studied using acyclovir as a model substrate [53]. Potential ocular or ocularsystemic drug-drug interactions can also be investigated using such in vivo and ex vivo methodologies $[74,75]$. Some of the ocular tissues including cornea and retina can be excised and the permeability of compounds studied across the sections. Ex vivo studies with isolated cornea [49, $61,62]$ and isolated retina $[65,76]$ have been conducted to determine the permeability of molecules and the role of transporters.

Some of the new technologies being explored to study transporters involve the use of antibodies to knock out transporters and study their role in drug pharmacokinetics [77]. A second technique is the inhibition of transporters, using siRNA [78, 79], to study the role of transporters. These are fairly new techniques which have not been thoroughly investigated for ophthalmic drug delivery. In vitro and ex vivo techniques can be used to rank order compounds. In conjunction with in vivo studies, the in vitro and ex vivo data can be used to conduct in vitro-in vivo correlations (IVIVC). Further refinement of these techniques needs to be conducted to adapt them to study the role of transporters in the eye.

Transporters in the Anterior Segment of the Eye The tissues/matrices in the anterior segment of the eye are conjunctiva, cornea, aqueous humor, lens, lens capsule, iris, ciliary body and trabecular meshwork. Transporters are known to be expressed in the conjunctiva, cornea, lens, iris and ciliary body. However, our major focus will be on transporters in the conjunctiva and cornea while only mentioning the transporters in the lens and ICB [47, 49, 51, 80-84].

\section{Drug Transporters in the Conjunctiva}

As most of the topical ocular administered drugs and xenobiotics come in contact with the conjunctiva, it is very well equipped to regulate their absorption into the eye and presents one of the very first barriers to topical ocular drug delivery. Yang et al. demonstrated the role of P-gp in limiting propranolol transport in rabbit conjunctival epithelial cells [80]. They also demonstrated the expression, localization and function of MRP1 in rabbit conjunctival epithelial cells [81]. Ueda et al. demonstrated the function of organic cation transporting system in excised pigmented rabbit conjunctiva [47]. Garrett et al. demonstrated the expression and localization of OCTN1 and OCTN2 in human corneal and conjunctival cells, as well as their role in carnitine uptake [59]. An excellent review on the role of conjunctiva in ocular drug delivery is available [48]. Figure 1 shows some of the transport processes that take place in the conjunctival epithelium.

Presence and activity of other relevant transporters like PepT1 and PepT2 in pigmented rabbit conjunctiva was reported by Sun et al. [85], while Basu et al. demonstrated their function in cultured rabbit conjunctival epithelial cells [86]. Other transporters and ion and fluid transport mechanisms exist in the conjunctiva.

\section{Drug Transporters in the Cornea}

Transporters in the corneal epithelium are outlined in Figure 2 [9]. There are both uptake and efflux transporters, for both large and small molecules which can influence drug exposures. These transporters serve to transfer molecules across the epithelium in either direction (towards the tear film or towards the aqueous humor). Studies on 


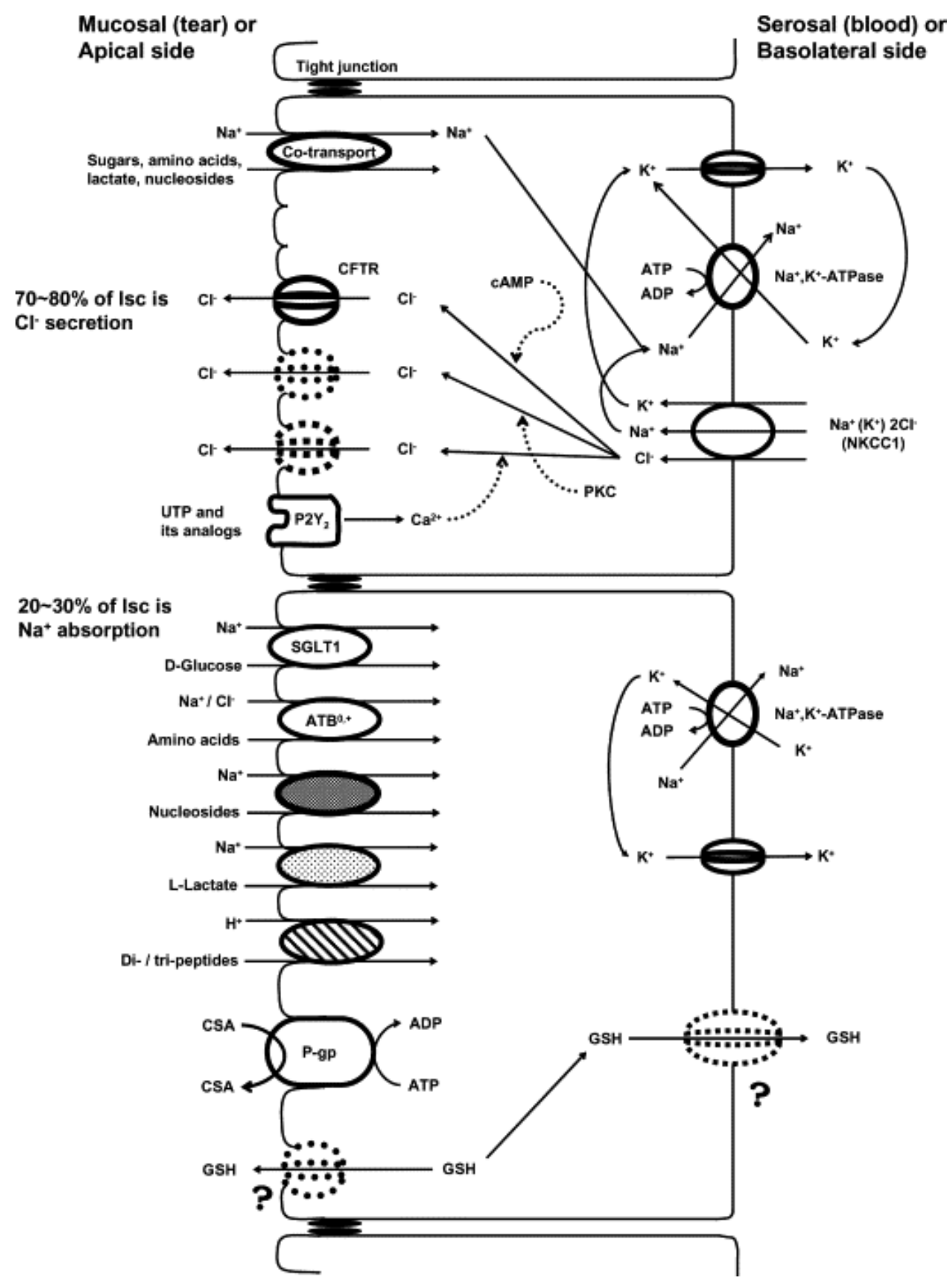

Figure 1: Ion and solute transport processes in the conjunctiva. Some transport processes (e.g. Na+-independent, carriermediated processes) are not shown for clarity, especially those localized at the serosal (or basolateral) aspect of the conjunctiva. Reproduced from Hosoya et al. [48] with permissions.

acyclovir and acyclovir prodrugs demonstrated not only that peptide transporters like PepT1 are present on the corneal epithelium, but also play an active role in the transport of these prodrugs. The presence of a facilitative transporter, OATP2A1, has been demonstrated in cornea, conjunctiva, iris and ciliary body and its role in the permeability of both latanoprost and its free acid metabolite was reported [87]. Vakkalagadda et al. demonstrated the expression and functionality of LAT1 (sodium independent neutral amino acid transporters) in excised rabbit cornea and the SIRC cell line [49]. The role of efflux transporters like MRP1, MRP2 and MRP5, using MDCK cell lines over- 


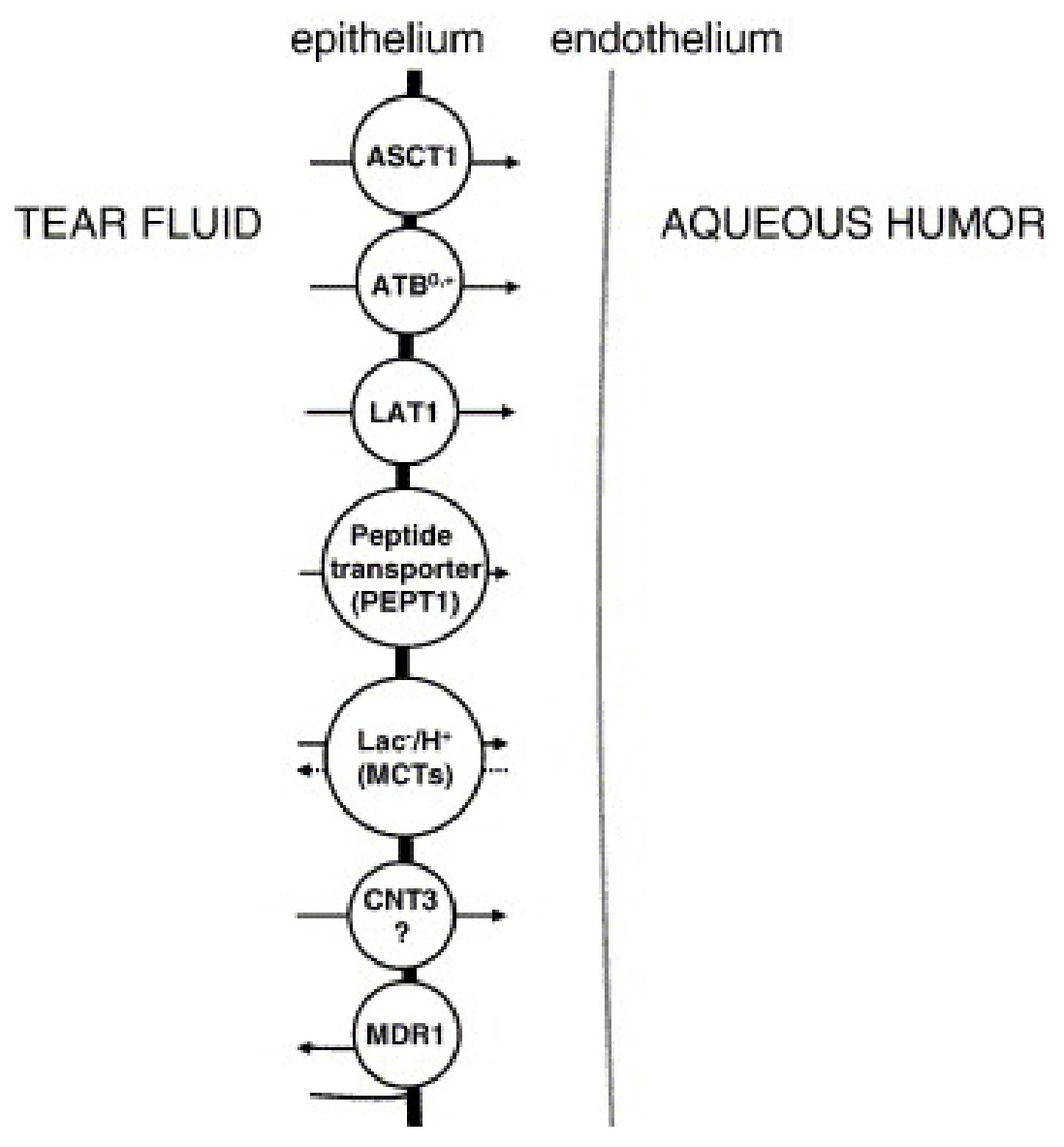

Figure 2: Currently known functional transporters in the corneal epithelium. MDR1- P-glycoprotein; CNT3- Concentrative nucleoside transporter 3; PEPT1- Peptide transporter1; MCTa- Monocarboxylate transporter a; LAT- L- amino acid transporter; ATB- Sodium dependent amino acid transporter; ASCT1- Alanine Serine Cysteine Transporter1. Reproduced from Mannermaa et al. with permissions [9].

expressing these transporters and excised rabbit cornea in the transport of prostaglandin analogues was also demonstrated [82]. The role of MRP5 in ocular uptake has been shown using acyclovir in human and rabbit corneal epithelial cells as well as ex vivo and in vivo studies in rabbits [53]. Furthermore, the efflux nature of P-gp and MRP2 in rabbit cornea and their action on erythromycin have also been reported [73, 88, 89]. Vellonen et al. reported significant expression and localization of MRP1, MRP5 and BCRP in human corneal epithelium; with no significant expression of MDR1 (P-gp), MRP2, MRP3, MRP4 and MRP6 [90], which agrees with previous reports [91]. Vellonen et al. [90] studied the expression and function of monocarboxylate transporters in human corneal epithelial and rabbit cornea cells. They demonstrated that MCT1 and MCT4 played a role in L-lactic acid and benzoic acid permeability and could be subjected to inhibition by employing inhibitors [92].

\section{Drug Transport in the Iris-ciliary Body (ICB) and the Lens}

The lens is rich in nutrient transporters and ion channels to maintain the osmotic and refractive nature. A glucose transporter was shown to be present in the ciliary body of human and rat eye [93], and a nucleoside transporter was demonstrated in rabbit ICB [94]. Amino acid transporters, potassium chloride co-transporters (KCC), glucose transporter (GLUT1 and GLUT 3) and vitamin C transporter have been identified in the lens to date $[50,51,83,84,95,96]$. The presence and function of these and other transporters in the anterior segment tissues indicate an integral role for the transporters in the functioning of the eye. 


\section{Transporters in the Posterior Segment of the Eye}

\section{Drug Transporters in the Retinal Pigmented Epithelium (RPE) and Retina}

P-gp expression and functional activity has been identified in RPE [72, 97-99]. For instance, P-gp was detected (presence of mdr1 mRNA) by RT-PCR in cultured human RPE and it was suggested that the basolateral P-gp would protect the neural retina by expelling unwanted substances from the subretinal space [97]. However, it was also reported that P-gp was present in the apical surface as well, which could indicate additional functions in the RPE [97]. Similarly, using the same approach it was determined that P-gp is expressed in the human RPE cells lines: D407 and h1RPE, but not in ARPE19. However, functional P-gp was only demonstrated in D407 cells [98].

MRP1 was expressed and identified in human retinal pigment epithelial (ARPE-19) cell line and primary cultures of human retinal pigment epithelial (HRPE) cells [100], as well as in the choroidal side of the outer BRB [101]. In the case of peptide transporters, ASCT2 (SLC1A5) was expressed in retinal Muller cells and it was suggested that this transporter also serves as an effluxer of D-serine [102]. Similarly, PepT-2 mRNA has been reported on retinal Muller cells [103] and also on retina when vitreous clearance of cephalosporins was studied using ocular microdialysis [104]. Furthermore, PHT1 has been reported to be expressed in bovine RPE (BRPE), human RPE (HRPE) cells, ARPE-19 (human RPE cell line), and bovine and human neural retina [105], while PEPT2 and PHT2 were only expressed in bovine and human retina [105]. It has also been reported that PEPT2 was identified on the RPE side facing the blood compartment [106, 107] and on the retina side facing the vitreous humor [103, 107]. For this reason, PEPT2 has been proposed as a target to increase intracellular concentrations in the retina following intravitreal administration or to enhance retinal concentrations following systemic administration [107].

Retina is considered to be the ocular tissue with the highest metabolic rate per weight [108]. This is primarily because the retina is considered an outgrowth of the developing brain and has similar neural constituents that require an active protection system as seen in brain tissue [109]. One of these protection systems is the blood-retinal barrier (BRB), which is formed by tight junctions between the cells of the RPE and the endothelial cells of the capillaries and prevents the leakage of protein or fluid from the vasculature into the retina [110]. For instance, Figure 3 represents the transporters at another barrier- a barrier to drug delivery to the back of the eye, more popularly known as the BRB [9]. This figure shows the transporters at the outer and inner blood-retinal barriers. There are multiple uptake and efflux transporters and the localization of P-gp on both surfaces of the epithelium is puzzling and interesting. The transport across this epithelium is also a combination of paracellular, transcellular and active transport. This barrier is more complex than the $\mathrm{BAB}$ and represents a major hurdle for drug delivery to the back of the eye, both from topical ocular and non-topical delivery [9].

Furthermore, various glucose transporters facilitate the transport of glucose across the bloodaqueous barrier (BAB) and blood-retinal barrier (BRB) $[34,95]$. For instance, GLUT1, GLUT3 and GLUT4 are high affinity glucose transporters, while GLUT 2 is considered a low affinity glucose transporter. GLUT5 is a high affinity fructose transporter [95]. In the case of GLUT 1 it was reported in RPE, choroid, par plasma, lens fiber cells and retinal Mueller cells [111]. It has also been reported that amino acid transporters including glutamate, glycine, GABA, proline and tryptophan are present on the retina $[107,112]$. The GLUT1 glucose transporter is expressed in endothelial and epithelial barriers like the retinal capillary endothelium and RPE, which was studied in diabetic and nondiabetic human eyes [113].

Monocarboxylic acid transporters (MCTs), which transport pyruvate and lactate, among other carboxylic acids have been found in the retina [107, 114, 115]. Specifically, MCT1 has been reported on the apical membrane of rat RPE, while MCT3 has been described on the basolateral membrane [116]. Recently, a folate receptor (FR), which is a specialized carrier-mediated active transporter system, has been described in human derived retinoblastoma cell line (Y-79) [117]. Similarly, in the same cell line biotin has been reported to be transported via a human sodium dependent multivitamin transporter (hSMVT), which is a specialized carrier-mediated system for biotin uptake into retinoblastoma cells [118]. The same research group also reported a riboflavin transporter 


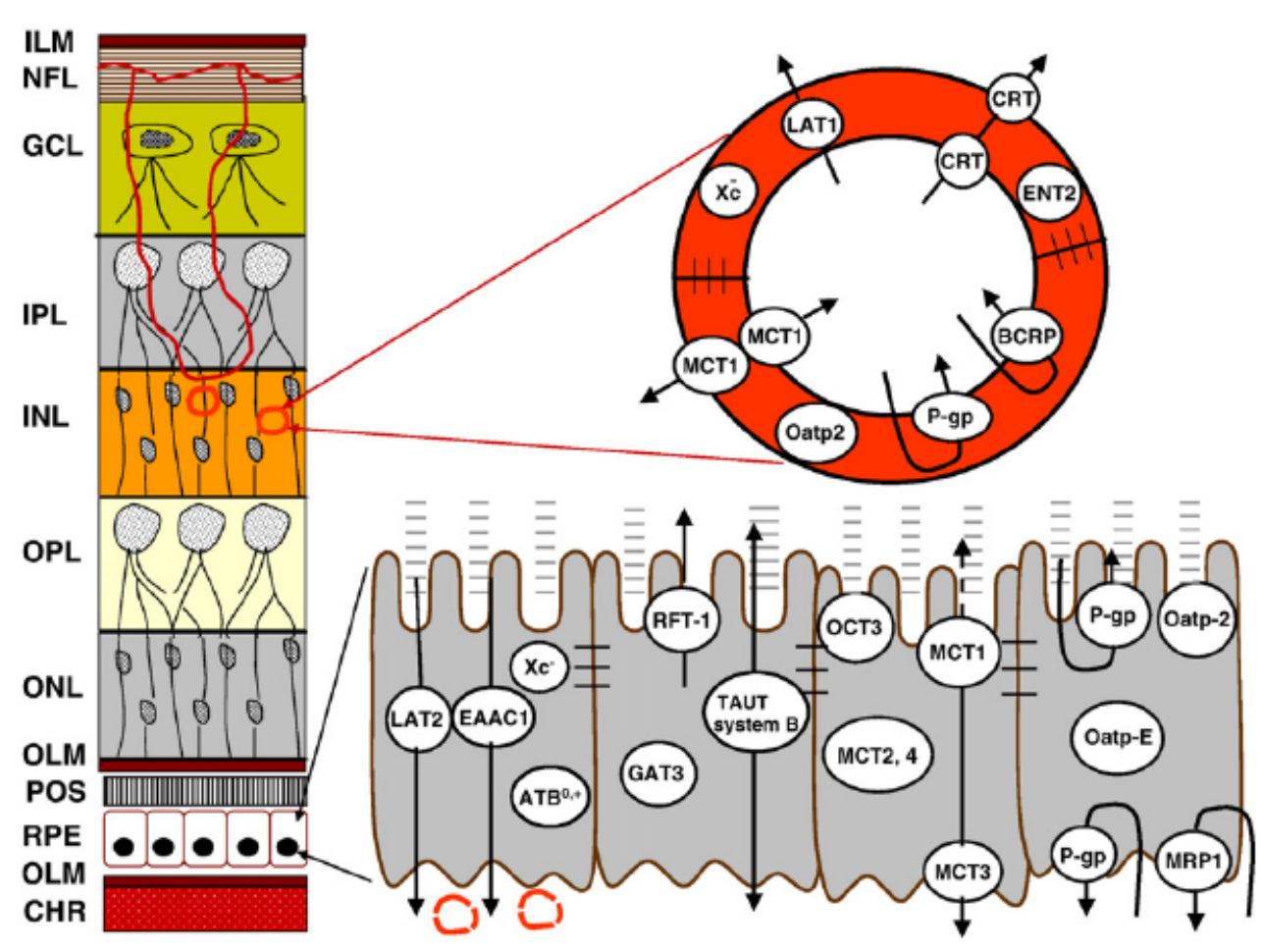

Figure 3: Schematic picture of the retina and of the transporters of outer and inner blood-retinal barriers. Abbreviations: ILM- inner limiting membrane; NFL- nerve fiber layer; IPL- inner plexiform layer; PL- outer plexiform layer; ONL- outer nuclear layer; OLM- outer limiting membrane; POS- photoreceptor outer segments; RPE- retinal pigment epithelium; BMBruchs membrane; CHR- choroids; MDR1- P-glycoprotein; MRP1- Multidrug resistance associated protein 1 transporter; OCT- Organic cation transporter; MCTa- Monocarboxylate transporter a; LAT- L- amino acid transporter; ATB- Sodium dependent amino acid transporter; OATP- Organic anion transporting polypeptide; BCRP- Breast cancer resistance protein transporter; CRT- Creatine Transporter; ENT- Equilibrative nucleoside transporter; GAT- gamma amino butyric acid transporter; TauT- Taurine Transporter. Reproduced from Mannermaa et al. [9] with permission.

in $\mathrm{Y}-79$ cells, which is a transporter system that is regulated by protein kinase $\mathrm{A}$ and $\mathrm{Ca}^{2+} /$ calmodulin pathways [119].

It needs to be mentioned that the water transport across the RPE and other ocular tissues has been reviewed elsewhere [109]. Briefly, the water transport across the RPE is mediated via an active solute-linked water transport via monocarboxylate transporter (MCT1 and MCT3) and via osmotic and hydrostatic forces that determine the other two passive mechanisms for water transport [109].

\section{ROLE OF TRANSPORTERS IN OCULAR DRUG DELIVERY - FRONT AND BACK OF THE EYE}

As stated above there is the presence of efflux and influx transporters in various ocular cell lines and tissues. While the efflux transporters lower the bioavailability of a drug by effluxing it out of the cell membrane and cytoplasm, the influx transporters will facilitate the translocation of a drug across biological membranes. Therefore, it can be understood that transporters play a crucial role for ocular drug delivery. It needs to be understood that the permeation of a drug through the eye will be dependent on the passive transport of the administered drug and its concentration gradient [9]. Keeping in mind that active transport is against the concentration gradient and needs energy, careful consideration needs to be taken for an ophthalmic drug, considering that transporter proteins may become saturated at high concentrations. This is highly relevant after intravitreal injection when there is a high local concentration in the vitreous humor. It needs to be mentioned that choroidal vessels present fenestrations from which a drug can 
escape this vasculature and leak out to the RPE and then reach the neural retina and vitreous humor. Thus, a drug can enter the vitreous humor and retina via the retinal capillaries or the blood stream of the choroid $[9,120]$.

The gene expression of both uptake and efflux transporters in different parts of the eye was measured by Zhang et al. [121]. Based on their findings, MRP1 seems to be a more important efflux transporter for the eye compared to P-gp. However, as is the usual case, more attention has been devoted to P-gp than to MRP1 in functional assays. As far as the facilitative transporters are concerned, OATPs, PEPT2, OCTs, OCTNs seem to be important for the eye. Though the expression, presence and localization of these transporters have been studied by Zhang et al. [121], the functional activity of all these transporters has not been well characterized. In other words, the presence or expression of a transporter indicates that the transporters might be functionally active, but does not guarantee it. The functional activity also needs to be demonstrated.

As presented, many of the ocular transporters have been cloned and expressed in various ocular cell lines and tissues. Some of them are involved in various processes including absorption, distribution and excretion of ophthalmic drugs. Because this is a very active field of study, various drug delivery approaches are taken to develop more effective therapeutic agents. The challenges to effectively deliver drugs to the posterior part of the eye following topical ocular administration are well known. The first barrier is the high tear turnover rate which will wash off or dilute the dose of the administered drug causing precorneal loss [10]. Then, there is the presence of efflux and influx transporters in the eye, the blood-aqueous barrier $(\mathrm{BAB})$ and blood-retinal barrier (BAB). Presented below will be various approaches that have been pursued to circumvent these issues. For example, transporter-targeted prodrug delivery has been utilized to improve bioavailability in the eye.

\section{Efflux Transporters}

Some of the efflux transporters that have been characterized in ocular cell lines and tissues include P-gp in cornea, conjunctiva and RPE cell lines [73, $80,122-124] ; \quad$ MRP1 in rabbit conjunctival epithelial cells and RPE [81, 100], MRP2 [89] and MRP5 [53] in corneal epithelium; as well as BCRP
[52] also in the corneal epithelium.

To date, the role of P-gp has been the most studied, as was the case with oral route of drug delivery. The localization and functional activity of P-gp and MRP in porcine eyes was demonstrated [101]. The molecular evidence and functional expression of MRP2 in human corneal epithelium and rabbit cornea and its role in ocular drug efflux was demonstrated [125]. Dey et al. [73] demonstrated the effect of P-gp in erythromycin pharmacokinetics in rabbit and human cornea. The corneal AUC of erythromycin in the presence of testosterone, a P-gp inhibitor, was significantly increased indicating a role for P-gp in influencing corneal drug bioavailability. MRP1 has not received much attention despite the evidence presented by Zhang et al. [121] and more studies are warranted. Some ophthalmic relevant drugs with their mode of administration along with the uptake and efflux transporters affecting their disposition is given in Table 2 [9].

\section{Influx Transporters}

In the case of ocular influx transporters there are mainly amino acid and peptide transporters [12]. For instance, ASCT1 (SLC1A4), a neutral amino acid transporter that belongs to the SLC1 gene family has been detected in rabbit cornea and in rPCEC (rabbit primary corneal epithelial cells) [63]. Similarly, ASCT2 (SLC1A5) was expressed in retinal Muller cells and it was suggested that this transporter also serves as an effluxer of D-serine [102]. The neutral and cationic amino acid transporter $\mathrm{B}^{0,+}$ (SLC6A14) has been found to be expressed in rabbit cornea, rabbit corneal epithelium and human cornea and to be involved in the L-arginine transport across corneal epithelium [126] but also across pigmented rabbit conjunctiva [127]. Furthermore, the Na+-independent large neutral amino acid transporter LAT1 (SLC7A5) was identified in human and rabbit cornea [49], while LAT2 (SLC7A8) was identified in the posterior segment [using an in vitro human model using RPE cell line (hTERT-RPE)] [128] and in ARPE-19 cells where it was determined to be involved in L-phenylalanine transport [129].

The peptide transporters are proton coupled transporters that contribute to the translocation of di- and tripeptides across the epithelium [130] and are mainly classified into PepT1, PepT2 and peptide/histidine transporters (PHT1 and PHT2) 
Table 2: Selected ocular drugs and suggested interactions with transporters. Reproduced from Mannermaa et al. [9].

\begin{tabular}{|c|c|c|c|}
\hline Drug & $\begin{array}{l}\text { Mode of } \\
\text { Administration }\end{array}$ & Transporter $^{\mathrm{a}}$ & References \\
\hline \multicolumn{4}{|l|}{ Antibiotics } \\
\hline Ampicillin & $\begin{array}{l}\text { Topical, intravitreal, } \\
\text { subconjunctival }\end{array}$ & Mouse Npt1, PEPT1, rat Pept2 & {$[95,166,167]$} \\
\hline Carbenicillin & $\begin{array}{l}\text { Topical, intravitreal, } \\
\text { subconjunctival }\end{array}$ & Rat Oat1, rabbit OAT & {$[168,169]$} \\
\hline Cefazolin & $\begin{array}{l}\text { Topical, intravitreal, } \\
\text { subconjunctival }\end{array}$ & OAT1, OAT2, OAT3, OAT4 & {$[170,171]$} \\
\hline Ceftazidime & $\begin{array}{l}\text { Intravitreal, } \\
\text { subconjunctival }\end{array}$ & Rat Oat1 & {$[168]$} \\
\hline Penicillin G & $\begin{array}{l}\text { Topical, } \\
\text { subconjunctival }\end{array}$ & $\begin{array}{l}\text { OAT1, OAT3, OAT4, OATP1B1, OATP1B3, rat } \\
\text { Oatp1a1, rat Oat1a3_v2, NPT1, PEPT1 }\end{array}$ & {$[172-181]$} \\
\hline Ciprofloxacin & Topical, intravitreal & $\begin{array}{l}\mathrm{BCRP} \text {, rabbit MCT, mouse MRP-like transporter, } \\
\text { rat Oct1 }\end{array}$ & {$[115,182-186]$} \\
\hline Norfloxacin & Topical & BCRP & {$[185]$} \\
\hline Levofloxacin & Topical & $\begin{array}{l}\text { Mouse MRP-like transporter, OCT2-A, rat } \\
\text { Oatp1a3 v2, P-gp }\end{array}$ & $\begin{array}{l}{[178,183,184,187,} \\
188]\end{array}$ \\
\hline Ofloxacin & Topical & BCRP, rabbit MCT, MRP1, rat Oct, rat P-gp & {$[115,185,189-191]$} \\
\hline Erythromycin & $\begin{array}{l}\text { Topical, intravitreal, } \\
\text { subconjunctival }\end{array}$ & $\begin{array}{l}\text { MRP1, OAT2, OATP1A2, rat Oatp1a4, rat } \\
\text { Oatp1b2, P-gp }\end{array}$ & {$[189,192-195]$} \\
\hline Tetracycline & Topical & OAT1, OAT2, OAT3, OAT4 & {$[196]$} \\
\hline Fusidate & Topical & Rat Bsep, rat Mrp2 & [197] \\
\hline \multicolumn{4}{|l|}{ Antifungal agents } \\
\hline Clotrimazole & Topical & MRP1 & {$[198]$} \\
\hline Miconazole & $\begin{array}{l}\text { Topical, intravitreal, } \\
\text { subconjunctival }\end{array}$ & P-gp & [199] \\
\hline \multicolumn{4}{|l|}{ Anti-viral drugs } \\
\hline Acyclovir & Topical & OAT1, rat Oat1, OCT1 & {$[200,201]$} \\
\hline Cidofovir & Intravitreal, systemic & OAT1, rat Oat1 & {$[202,203]$} \\
\hline Foscarnet & Intravitreal, systemic & Rat Mct1, mouse Npt1 & {$[167,204]$} \\
\hline Ganciclovir & Intravitreal, systemic & MRP4, OAT1, OCT1 & {$[201,205]$} \\
\hline Idoxuridine & Topical & Rat Cnt1, rabbit CNT3 & {$[206,207]$} \\
\hline Trifluridine & Topical & Rat Oat1 & [200] \\
\hline Valacyclovir & Systemic & Mouse $\mathrm{ATB}^{0,+}$, OAT3, human PEPT1, rat Pept2 & {$[201,208-210]$} \\
\hline Zidovudine (AZT) & Systemic & $\begin{array}{l}\text { BCRP, rat Cnt1, MRP4, OAT1, rat Oat1, OAT2, } \\
\text { OAT3, OAT4, rat Oat1p1a3 v1, rat Oatp1a3 v2 }\end{array}$ & {$[200,201,211-215]$} \\
\hline \multicolumn{4}{|c|}{ Anti-inflammatory agents } \\
\hline Dexamethasone & $\begin{array}{l}\text { Topical, intravitreal, } \\
\text { subconjunctival }\end{array}$ & $\begin{array}{l}\text { BCRP, OATP1A2, rat Oatp1a1, rat Oatp1a3_v2, } \\
\text { P-gp }\end{array}$ & {$[177,216-221]$} \\
\hline Hydrocortisone & Topical & Rat Oatp1a1, P-gp & {$[222,223]$} \\
\hline $\begin{array}{l}\text { Methylprednisolon } \\
\text { e }\end{array}$ & Subconjunctival & P-gp & {$[218]$} \\
\hline $\begin{array}{l}\text { Prednisolone } \\
\text { Triamcinolone }\end{array}$ & $\begin{array}{l}\text { Topical } \\
\text { Intravitreal }\end{array}$ & $\begin{array}{l}\text { OATP1B3 }{ }^{\mathrm{b}} \text {, rat Oatp1a1, rat Oatp1a3_v2, P-gp } \\
\text { BCRP }^{\mathrm{c}}\end{array}$ & $\begin{array}{l}{[178,181,218,221]} \\
{[216,217]}\end{array}$ \\
\hline \multicolumn{4}{|c|}{ Nonsteroidal anti-inflammatory drugs (NSAIDs) } \\
\hline Diclofenac & Topical & $\begin{array}{l}\text { OAT1, OAT2, OAT3, OAT4, OCT1, rat Oat2, } \\
\text { rabbit MCT }\end{array}$ & {$[115,174,215,224]$} \\
\hline Flurbiprofen & Topical & Rabbit MCT, OAT1 & {$[115,225]$} \\
\hline \multicolumn{4}{|c|}{ Antifibrotic agents } \\
\hline 5-Fluorouracil & $\begin{array}{l}\text { Topical, intravitreal, } \\
\text { subconjunctival }\end{array}$ & MRP5, MRP8 & {$[226,227]$} \\
\hline
\end{tabular}

Cont'd. 
Table 2 Cont'd.

\begin{tabular}{|c|c|c|c|}
\hline Drug & $\begin{array}{l}\text { Mode of } \\
\text { Administration }\end{array}$ & Transporter $^{\mathrm{a}}$ & References \\
\hline \multicolumn{4}{|c|}{ Antiglaucoma drugs } \\
\hline Carbachol & Topical & Rabbit OCT & [47] \\
\hline Brimonidine & Topical & OCT & {$[47,228]$} \\
\hline Dipivefrine & Topical & Rabbit OCT & [47] \\
\hline Timolol & Topical & OCT, P-gp & {$[229,230]$} \\
\hline $\begin{array}{l}\text { Unosprostone } \\
\text { carboxylate }^{\mathrm{d}}\end{array}$ & Topical & OATP1A2, OATP2B1, OATP4A1 & {$[231]$} \\
\hline \multicolumn{4}{|c|}{ H1 receptor antagonists } \\
\hline Azelastine & Topical & P-gp & {$[232]$} \\
\hline Ketotifen & Topical & P-gp & [233] \\
\hline \multicolumn{4}{|c|}{ Immunomodulators } \\
\hline Cyclosporine & Topical & $\begin{array}{l}\text { BCRP, MRP1, MRP2, OATP1B1, OATP1B3, } \\
\text { OATP2B1m rat Oatp1a1, rat Oatp1a4, P-gp }\end{array}$ & {$[180,181,234-237]$} \\
\hline \multicolumn{4}{|c|}{ Diagnostic agents } \\
\hline Fluorescein & Topical, intravenous & MCT, MRP1, OAT1, mouse Oat3 & {$[238-243]$} \\
\hline $\begin{array}{l}\text { Systemic: oral } \\
{ }^{\mathrm{a} C} \text { Capital letters } \\
{ }^{\mathrm{b}} \text { Prednisolone } \\
{ }^{\mathrm{c}} \text { Contradictory } \\
{ }^{\mathrm{d}} \text { De-esterified }\end{array}$ & $\begin{array}{l}\mathrm{r} \text { intravenous (IV) } \\
\text { n transporter } \\
\text { ate } \\
\text { s }\end{array}$ & & \\
\hline
\end{tabular}

[34]. The peptide transporters PEPT1 and PEPT2 have been detected on clonetics human corneal epithelium (cHCE) and on human cornea [121, 131]. Furthermore, PepT-2 mRNA has been reported on retinal Muller cells [103] and also on retina when vitreous clearance of cephalosporins were studied using ocular microdialysis [104]. Various drugs have been reported to be substrates of these transporters; for instance, $\beta$-lactam antibiotics, and renin- and ACE-inhibitors are substrates for PepT1 and PepT2 [34]. More studies to correlate protein expression and localization of peptide transporters to transport activity are necessary to better understand their relevance to ocular drug delivery. Nevertheless, monocarboxylate (SLC16), organic cation/anion (SLC22), nucleoside (SLC28 and SLC29), and vitamin transporters have been reported in various ocular tissues [12, 61, 132-134]. Atluri et al. demonstrated the role of an oligopeptide transporter in glycosarcosine ocular bioavailability. The transporter inhibitors decreased the ocular bioavailability of glycosarcosine [106].

As described above there are various transporters that have been identified in ocular cell lines and tissues. Therefore, various approaches have been pursued to circumvent efflux transporters or to take advantage of the influx transporters. The most common approach is using transportertargeted prodrugs (Table 3) [12]. This approach has led to improvements in ocular bioavailability of various drugs since it takes advantage of the ocular influx transporters or due to changes in physicochemical properties in the prodrugs or by a combination of these two factors. In general, the prodrugs are recognized by the ocular membrane transporters as substrates and allow their translocation across the epithelia. So far this approach has been undertaken for transportertargeted drug delivery to cornea, conjunctiva and RPE [12]. For instance, studies on acyclovir and acyclovir prodrugs demonstrated not only that peptide transporters like PepT1 are present on the corneal epithelium, but also play an active role in the transport of these prodrugs. The presence of a facilitative transporter, OATP2A1, was demonstrated in cornea, conjunctiva, iris and ciliary body and its role in the permeability of both latanoprost and its free acid metabolite was reported [87]. More examples are presented in the section below. 
Table 3. Transported-Targeted Prodrugs for Ocular Drug Delivery (modified from Gaudana et al. [12] with permission).

\begin{tabular}{|c|c|c|c|}
\hline $\begin{array}{l}\text { Transporter } \\
\text { System-targeted } \\
\text { Tissue/cell Line }\end{array}$ & $\begin{array}{l}\text { Drug/prodrug } \\
\text { Employed }\end{array}$ & Observation & Reference \\
\hline $\mathrm{B}^{0,+}$ on the cornea & L-asparate ACV & $\begin{array}{llll}\text { Four-fold higher transcorneal permeability } & \text { of } \\
\text { L-aspartate ACV compared to ACV } & & \\
\end{array}$ & {$[244]$} \\
\hline $\mathrm{B}^{0,+}$ on the cornea & $\begin{array}{l}\text { Gamma-glutamate- } \\
\text { ACV (EACV) }\end{array}$ & $\begin{array}{l}\text { Higher aqueous solubility of the prodrug along with the } \\
\text { transporter recognition }\end{array}$ & {$[245]$} \\
\hline $\mathrm{B}^{0,+}$ on the cornea & $\begin{array}{l}\text { Phenylalanine-ACV } \\
\text { and EACV }\end{array}$ & $\begin{array}{l}\text { The prodrugs inhibited the transport of } \mathrm{L} \text {-arginine }{ }^{\mathrm{a}} \\
\text { across the cornea implied that they are substrates of } \mathrm{B}^{0,+}\end{array}$ & {$[126]$} \\
\hline $\begin{array}{l}\text { OPT system on the } \\
\text { cornea }\end{array}$ & L-valine ACV & $\begin{array}{llll}\text { Three-fold higher transcorneal } & \text { permeability } & \text { of } \\
\text { L-valine ACV compared to ACV } & & \\
\end{array}$ & {$[157]$} \\
\hline $\begin{array}{l}\text { OPT system on the } \\
\text { cornea }\end{array}$ & $\begin{array}{l}\text { Gly-Val-GCV, Val- } \\
\text { Val-GCV and Tyr-Val- } \\
\text { GCV }\end{array}$ & $\begin{array}{l}\text { Significant transcellular passive diffusion and } \\
\text { transporter recognition resulted in higher } \mathrm{AUC} \text { and } \mathrm{C}_{\max }\end{array}$ & {$[246,247]$} \\
\hline $\begin{array}{l}\text { OPT system on } \\
\text { rPCEC cells and } \\
\text { the cornea }\end{array}$ & $\begin{array}{l}\text { Val-quinidine and Val- } \\
\text { Val-quinidine }\end{array}$ & $\begin{array}{l}\text { Prodrugs were not recognized by P-gp efflux pump and } \\
\text { further found to be substrates of peptide transporters }\end{array}$ & {$[248]$} \\
\hline $\begin{array}{l}\text { OPT system on the } \\
\text { retina }\end{array}$ & $\begin{array}{l}\text { Gly-Val-GCV, Val- } \\
\text { Val-GCV and Tyr-Val- } \\
\text { GCV }\end{array}$ & $\begin{array}{l}\text { Two-fold higher RCS tissue permeability than that of } \\
\text { GCV due to higher lipophilicity and translocation } \\
\text { mediated by OPT across RPE }\end{array}$ & [249] \\
\hline $\begin{array}{l}\text { SMVT on the } \\
\text { retina }\end{array}$ & Biotin-GCV & $\begin{array}{l}\text { Higher biotin-GCV permeability into the retina-choroid } \\
\text { and slower elimination from vitreous }\end{array}$ & {$[250]$} \\
\hline $\begin{array}{l}\text { GLUT1 on the } \\
\text { HRPE cells }\end{array}$ & Glu-dopamine & Transporter recognizes prodrug, not the parent drug & [251] \\
\hline
\end{tabular}

OPT oligopeptide transporter, SMVT sodium-dependent multiple vitamin transporter, $\mathrm{B}^{0,+}$ amino acid transporter, GLUT glucose transporter, rPCEC rabbit primary corneal epithelial cells, HRPE human retinal pigment epithelium cells, RCS retina-choroid-sclera, ACV acyclovir, GCV ganciclovir, RPE retinal pigment epithelium

${ }^{\mathrm{a}}$ Substrate of $\mathrm{B}^{0,+}$

\section{FORMULATION DEVELOPMENT INCLUDING PRO-DRUG APPROACH EFFECTING TRANSPORTERS}

A majority of ocular diseases are treated using topical ocular administration. A major drawback of this route has been the poor residence time which leads to very little drug absorption into the intraocular tissues. Viscosifying agents like tamarind gum, HPMC, cremophor, CMC, xanthan gum, etc., have been investigated and reported to increase drug residence time on the surface of the eye [135-143]. Some surface active agents like benzalkonium chloride and EDTA have been investigated for their penetration enhancing ability $[80,81,83,144-146]$. The intent of this section is to review any formulation approaches that affect transporters to enhance ocular drug exposures and bioavailability.

Formulation approaches have been used in oral and systemic drug delivery to modify transporter function and improve systemic bioavailability. A good example is Vitamin ETPGS which has been used in conjunction with amprenavir as an excipient to inhibit P-gp and improve the oral bioavailability of amprenavir [147]; a study with paclitaxel also demonstrated similar results [148]. Other commonly used excipients like cyclodextrins, Labrasol ${ }^{\mathrm{TM}}$, cremophor, polyethylene glycols (PEGs) and pluronics have also been shown to inhibit transporters [149-156]. While these approaches seem to be common in oral drug delivery, such an investigation is lacking in the field of ophthalmic drug delivery. Some of the above mentioned excipients like xanthan gum, EDTA, cremophor and PEGs, which are used in eye drops for topical ocular delivery have been shown to inhibit transporters and can potentially play a role in increasing ocular tissue exposures. However, studies to determine the contribution of transporter inhibition and increased residence time/penetration enhancement have not been done. Investigations into approaches to avoid transporters would be 
useful to improve ocular drug bioavailability. Prodrugs which are metabolized to the active moiety in vivo have been used in ocular drug delivery (Table 2). Latanoprost, when administered via topical ocular route is metabolized in vivo to its active form. It was demonstrated that OATP2A1, which is expressed in both RPE/choroid and anterior segment tissues like cornea, conjunctiva, iris and ciliary body, plays a role in the permeability of both latanoprost and its free acid metabolite [87]. In another study, it was demonstrated that bimatoprost and latanoprost and their free acid metabolites were substrates of MRP1, MRP2 and MRP5, using MDCK cell lines over-expressing these transporters and excised rabbit cornea [82]. Furthermore, it has been reported that acyclovir prodrugs, which utilize both ocular transporter and enzyme interplay can be used to deliver drugs to the eye [157-159].

\section{CURRENT AND FUTURE RELEVANCE OF OCULAR TRANSPORTERS IN DRUG DEVELOPMENT}

Many clinically available ophthalmic drugs are known to be either substrates or inhibitors of transporters, and are presented in this review. While the expression and presence of both facilitative and efflux transporters has been demonstrated, knowledge of their role in affecting ocular pharmacokinetics in preclinical species is limited. Their relevance to clinical ocular pharmacokinetics has not been demonstrated.

A drug-drug interaction between oral/systemically administered compounds and topical ocular administered compounds can occur where either of the molecules can be a victim or perpetrator of the interaction. Oral and systemically administered drugs can distribute to the eye due to the action of transporters. These molecules can interact with topically administered drugs altering their local ocular pharmacokinetics, safety and efficacy. In the same way, topically administered molecules can affect the ocular distribution of orally administered compounds by inhibiting the efflux transporters in blood-ocular barriers, of which the oral/systemically administered compounds are substrates. Hippalgoankar et al. in fact showed that such drug-drug interactions are possible by studying the interaction between a topically administered and systemically administered P-gp substrates/inhibitors [74]. Thus, these transporters play an important role in affecting the ocular disposition of the drugs and affect their therapeutic action of the drugs. At the same time such oral and systemically administered drugs distributing to the eye due to transporter mediated drug-drug interactions can cause unwanted ocular effects.

Interplay between enzymes and transporters, like CYP3A4 and P-gp has been well studied [160165]. However, the same cannot be said of ophthalmic drug delivery. Some of the prodrug approaches used in ocular drug delivery, which utilize the interplay of enzymes and transporters, are mentioned in this review. These studies demonstrate that ocular tissue levels of the active metabolite can be modified by the action of the efflux and facilitative transporters. Such studies demonstrate that enzyme transporter interplay is possible in ocular drug delivery and needs to be further investigated, either to the advantage of drug development and delivery or to prevent possible pitfalls which can arise due to genetic differences in the populations of transporters and enzymes.

Molecules which are designed to utilize body's existing transporter systems to improve their systemic and target organ/tissue bioavailability can be used to improve posterior segment drug exposures upon topical ocular delivery as also for decreasing systemic drug exposures upon intraocular (intravitreal or intracameral) administration. Such approaches are currently being tested in the clinic with oral drug delivery.

\section{CONCLUSIONS}

While the expression and presence of transporters in the eye has been well demonstrated, studies to understand their role in ocular drug delivery, vis-àvis their role in ocular pharmacokinetics, efficacy and safety, are only in their infancy. While the role of transporters in ocular homeostasis is known, a disruption of these mechanisms by drugs modifying transporter function needs to be studied. While the in vitro and in vivo techniques for investigating the role of transporters in ocular drug delivery already exist, intensive investigation needs to be carried out before their clinical relevance can be elucidated and understood. 


\section{ACKNOWLEDGEMENTS}

We would like to acknowledge James Chastain, Ph.D., Scott Womble, D.Sc., Gangadhar Sunkara, Ph.D., Charles Kiehlbauch, M.S., and Edith Anunciacion, B.S. for their expertise in reviewing this manuscript.

\section{REFERENCES}

1. W. Loscher, H. Potschka, Drug resistance in brain diseases and the role of drug efflux transporters, Nat Rev Neurosci, 6 (2005) 591-602.

2. J.F. Ghersi-Egea, K.S. Monkkonen, C. Schmitt, J. Honnorat, M. Fevre-Montange, N. Strazielle, Blood-brain interfaces and cerebral drug bioavailability, Rev Neurol (Paris), 165 (2009) 1029-1038.

3. S. Dallas, D.S. Miller, R. Bendayan, Multidrug resistance-associated proteins: expression and function in the central nervous system, Pharmacol Rev, 58 (2006) 140-161.

4. E. Aronica, S.M. Sisodiya, J.A. Gorter, Cerebral expression of drug transporters in epilepsy, Advanced drug delivery reviews, 64 (2012) 919929.

5. G. Lee, S. Dallas, M. Hong, R. Bendayan, Drug transporters in the central nervous system: brain barriers and brain parenchyma considerations, Pharmacol Rev, 53 (2001) 569-596.

6. V. Leviel, Dopamine release mediated by the dopamine transporter, facts and consequences, J Neurochem, 118 (2011) 475-489.

7. H. Kusuhara, Y. Sugiyama, Efflux transport systems for organic anions and cations at the bloodCSF barrier, Advanced drug delivery reviews, 56 (2004) 1741-1763.

8. M. Tomi, K. Hosoya, The role of blood-ocular barrier transporters in retinal drug disposition: an overview, Expert Opin Drug Metab Toxicol, 6 (2010) 1111-1124.

9. E. Mannermaa, K.S. Vellonen, A. Urtti, Drug transport in corneal epithelium and blood-retina barrier: emerging role of transporters in ocular pharmacokinetics, Advanced drug delivery reviews, 58 (2006) 1136-1163.

10. S. Dey, B.S. Anand, J. Patel, A.K. Mitra, Transporters/receptors in the anterior chamber: pathways to explore ocular drug delivery strategies, Expert Opin Biol Ther, 3 (2003) 23-44.

11. J.C. Robinson, Ocular Anatomy and Physiology Relevant to Ocular Drug Delivery, in: A.K. Mitra (Ed.) Opthalmic Drug Delivery Systems, 2003.

12. R. Gaudana, H.K. Ananthula, A. Parenky, A.K. Mitra, Ocular drug delivery, AAPS J, 12 (2010)
348-360.

13. F.J. Holly, Formation and stability of the tear film, Int Ophthalmol Clin, 13 (1973) 73-96.

14. D. Miller, Pressure of the lid on the eye, Arch Ophthalmol, 78 (1967) 328-330.

15. M.R. Allansmith, G.R. O'Connor, Immunoglobulins: structure, function and relation to the eye, Surv Ophthalmol, 14 (1970) 367-402.

16. A. Bill, The aqueous humor drainage mechanism in the cynomolgus monkey (Macaca irus) with evidence for unconventional routes, Invest Ophthalmol, 4 (1965) 911-919.

17. S. Bonnel, S. Mohand-Said, J.A. Sahel, The aging of the retina, Exp Gerontol, 38 (2003) 825-831.

18. D.W. DelMonte, T. Kim, Anatomy and physiology of the cornea, Journal of cataract and refractive surgery, 37 (2011) 588-598.

19. A.K. Horn, R.J. Leigh, The anatomy and physiology of the ocular motor system, Handb Clin Neurol, 102 (2011) 21-69.

20. S.P. Most, S.R. Mobley, W.F. Larrabee, Jr., Anatomy of the eyelids, Facial Plast Surg Clin North Am, 13 (2005) 487-492, v.

21. S. Kinoshita, W. Adachi, C. Sotozono, K. Nishida, N. Yokoi, A.J. Quantock, K. Okubo, Characteristics of the human ocular surface epithelium, Prog Retin Eye Res, 20 (2001) 639673.

22. J.T. Daniels, J.K. Dart, S.J. Tuft, P.T. Khaw, Corneal stem cells in review, Wound Repair Regen, 9 (2001) 483-494.

23. R.D. Fernald, Eyes: variety, development and evolution, Brain Behav Evol, 64 (2004) 141-147.

24. W.J. Gehring, Historical perspective on the development and evolution of eyes and photoreceptors, Int J Dev Biol, 48 (2004) 707-717.

25. K. Church, J.I. McGill, Human ocular mast cells, Curr Opin Allergy Clin Immunol, 2 (2002) 419422.

26. G.A. Cioffi, A. Alm, Measurement of ocular blood flow, J Glaucoma, 10 (2001) S62-64.

27. A. Malhotra, F.J. Minja, A. Crum, D. Burrowes, Ocular anatomy and cross-sectional imaging of the eye, Semin Ultrasound CT MR, 32 (2011) 2-13.

28. S.P. Bhat, The ocular lens epithelium, Biosci Rep, 21 (2001) 537-563.

29. D. Straumann, T. Haslwanter, Ocular motor disorders, Curr Opin Neurol, 14 (2001) 5-10.

30. M. Dieterich, Ocular motor system: anatomy and functional magnetic resonance imaging, Neuroimaging Clin N Am, 11 (2001) 251-261, viiiix.

31. J.E. Morgan, Optic nerve head structure in glaucoma: astrocytes as mediators of axonal damage, Eye (Lond), 14 ( Pt 3B) (2000) 437-444.

32. P.H. Phillips, The orbit, Ophthalmol Clin North 
Am, 14 (2001) 109-127, viii.

33. C.R. Blake, W.W. Lai, D.P. Edward, Racial and ethnic differences in ocular anatomy, Int Ophthalmol Clin, 43 (2003) 9-25.

34. R. Gaudana, J. Jwala, S.H. Boddu, A.K. Mitra, Recent perspectives in ocular drug delivery, Pharmaceutical research, 26 (2009) 1197-1216.

35. R.D. Schoenwald, V. Tandon, D.E. Wurster, C.F. Barfknecht, Significance of melanin binding and metabolism in the activity of 5-acetoxyacetylimino4-methyl-delta2-1,3,4,-thiadiazolin e-2sulfonamide, Eur J Pharm Biopharm, 46 (1998) 3950.

36. B. Leblanc, S. Jezequel, T. Davies, G. Hanton, C. Taradach, Binding of drugs to eye melanin is not predictive of ocular toxicity, Regul Toxicol Pharmacol, 28 (1998) 124-132.

37. B.S. Larsson, Interaction between chemicals and melanin, Pigment Cell Res, 6 (1993) 127-133.

38. A. Beberok, E. Buszman, D. Wrzesniok, M. Otreba, J. Trzcionka, Interaction between ciprofloxacin and melanin: the effect on proliferation and melanization in melanocytes, European journal of pharmacology, 669 (2011) 3237.

39. M. Fukuda, Y. Morita, K. Sasaki, Y. Yamamoto, Studies on the binding mechanism of fluoroquinolones to melanin, J Infect Chemother, 6 (2000) $72-76$.

40. M. Tanaka, H. Takashina, S. Tsutsumi, Comparative assessment of ocular tissue distribution of drug-related radioactivity after chronic oral administration of 14C-levofloxacin and $14 \mathrm{C}$-chloroquine in pigmented rats, $\mathrm{J}$ Pharm Pharmacol, 56 (2004) 977-983.

41. R.S. Kadam, U.B. Kompella, Influence of lipophilicity on drug partitioning into sclera, choroid-retinal pigment epithelium, retina, trabecular meshwork, and optic nerve, The Journal of pharmacology and experimental therapeutics, 332 (2010) 1107-1120.

42. A. Amrite, V. Pugazhenthi, N. Cheruvu, U. Kompella, Delivery of celecoxib for treating diseases of the eye: influence of pigment and diabetes, Expert Opin Drug Deliv, 7 (2010) 631645.

43. L. Salminen, G. Imre, R. Huupponen, The effect of ocular pigmentation on intraocular pressure response to timolol, Acta Ophthalmol Suppl, 173 (1985) 15-18.

44. L. Pitkanen, V.P. Ranta, H. Moilanen, A. Urtti, Binding of betaxolol, metoprolol and oligonucleotides to synthetic and bovine ocular melanin, and prediction of drug binding to melanin in human choroid-retinal pigment epithelium, Pharmaceutical research, 24 (2007) 2063-2070.
45. L. Pitkanen, V.P. Ranta, H. Moilanen, A. Urtti, Permeability of retinal pigment epithelium: effects of permeant molecular weight and lipophilicity, Invest Ophthalmol Vis Sci, 46 (2005) 641-646.

46. J.E. Chastain, General Considerations in Ocular Drug Delivery, in: A.K. Mitra (Ed.) Ocular Anatomy and Physiology Relevant to Ocular Drug Delivery, Marcel Dekker, New York, 2003.

47. H. Ueda, Y. Horibe, K.J. Kim, V.H. Lee, Functional characterization of organic cation drug transport in the pigmented rabbit conjunctiva, Invest Ophthalmol Vis Sci, 41 (2000) 870-876.

48. K. Hosoya, V.H. Lee, K.J. Kim, Roles of the conjunctiva in ocular drug delivery: a review of conjunctival transport mechanisms and their regulation, Eur J Pharm Biopharm, 60 (2005) 227240.

49. B. Jain-Vakkalagadda, S. Dey, D. Pal, A.K. Mitra, Identification and functional characterization of a $\mathrm{Na}$--independent large neutral amino acid transporter, LAT1, in human and rabbit cornea, Invest Ophthalmol Vis Sci, 44 (2003) 2919-2927.

50. K.S. Chee, J. Kistler, P.J. Donaldson, Roles for $\mathrm{KCC}$ transporters in the maintenance of lens transparency, Invest Ophthalmol Vis Sci, 47 (2006) 673-682.

51. B.R. Merriman-Smith, A. Krushinsky, J. Kistler, P.J. Donaldson, Expression patterns for glucose transporters GLUT1 and GLUT3 in the normal rat lens and in models of diabetic cataract, Invest Ophthalmol Vis Sci, 44 (2003) 3458-3466.

52. P.K. Karla, R. Earla, S.H. Boddu, T.P. Johnston, D. $\mathrm{Pal}, \mathrm{A}$. Mitra, Molecular expression and functional evidence of a drug efflux pump (BCRP) in human corneal epithelial cells, Curr Eye Res, 34 (2009) 19.

53. P.K. Karla, T.L. Quinn, B.L. Herndon, P. Thomas, D. Pal, A. Mitra, Expression of multidrug resistance associated protein 5 (MRP5) on cornea and its role in drug efflux, J Ocul Pharmacol Ther, 25 (2009) 121-132.

54. N.J. Hewitt, M.J. Lechon, J.B. Houston, D. Hallifax, H.S. Brown, P. Maurel, J.G. Kenna, L. Gustavsson, C. Lohmann, C. Skonberg, A. Guillouzo, G. Tuschl, A.P. Li, E. LeCluyse, G.M. Groothuis, J.G. Hengstler, Primary hepatocytes: current understanding of the regulation of metabolic enzymes and transporter proteins, and pharmaceutical practice for the use of hepatocytes in metabolism, enzyme induction, transporter, clearance, and hepatotoxicity studies, Drug Metab Rev, 39 (2007) 159-234.

55. Y. Shitara, A.P. Li, Y. Kato, C. Lu, K. Ito, T. Itoh, Y. Sugiyama, Function of uptake transporters for taurocholate and estradiol 17beta-D-glucuronide in cryopreserved human hepatocytes, Drug Metab 
Pharmacokinet, 18 (2003) 33-41.

56. E.L. LeCluyse, K.L. Audus, J.H. Hochman, Formation of extensive canalicular networks by rat hepatocytes cultured in collagen-sandwich configuration, Am J Physiol, 266 (1994) C17641774.

57. G. Ghibellini, L.S. Vasist, E.M. Leslie, W.D. Heizer, R.J. Kowalsky, B.F. Calvo, K.L. Brouwer, In vitro-in vivo correlation of hepatobiliary drug clearance in humans, Clinical pharmacology and therapeutics, 81 (2007) 406-413.

58. S. Xu, J.L. Flanagan, P.A. Simmons, J. Vehige, M.D. Willcox, Q. Garrett, Transport of L-carnitine in human corneal and conjunctival epithelial cells, Mol Vis, 16 (2010) 1823-1831.

59. Q. Garrett, S. Xu, P.A. Simmons, J. Vehige, J.L. Flanagan, M.D. Willcox, Expression and localization of carnitine/organic cation transporter OCTN1 and OCTN2 in ocular epithelium, Invest Ophthalmol Vis Sci, 49 (2008) 4844-4849.

60. K. Jager, U. Bonisch, M. Risch, D. Worlitzsch, F. Paulsen, Detection and regulation of cationic amino acid transporters in healthy and diseased ocular surface, Invest Ophthalmol Vis Sci, 50 (2009) 1112-1121.

61. S. Hariharan, K.G. Janoria, S. Gunda, X. Zhu, D. Pal, A.K. Mitra, Identification and functional expression of a carrier-mediated riboflavin transport system on rabbit corneal epithelium, Curr Eye Res, 31 (2006) 811-824.

62. S. Majumdar, G.S. Tirucherai, D. Pal, A.K. Mitra, Functional differences in nucleoside and nucleobase transporters expressed on the rabbit corneal epithelial cell line (SIRC) and isolated rabbit cornea, AAPS PharmSci, 5 (2003) E15.

63. S. Katragadda, R.S. Talluri, D. Pal, A.K. Mitra, Identification and characterization of a $\mathrm{Na}+-$ dependent neutral amino acid transporter, ASCT1, in rabbit corneal epithelial cell culture and rabbit cornea, Curr Eye Res, 30 (2005) 989-1002.

64. S. Ananth, S. Karunakaran, P.M. Martin, C.N. Nagineni, J.J. Hooks, S.B. Smith, P.D. Prasad, V. Ganapathy, Functional identification of a novel transport system for endogenous and synthetic opioid peptides in the rabbit conjunctival epithelial cell line CJVE, Pharmaceutical research, 26 (2009) 1226-1235.

65. S. Majumdar, S. Macha, D. Pal, A.K. Mitra, Mechanism of ganciclovir uptake by rabbit retina and human retinal pigmented epithelium cell line ARPE-19, Curr Eye Res, 29 (2004) 127-136.

66. P.P. Chothe, S.V. Thakkar, J.P. Gnana-Prakasam, S. Ananth, D.R. Hinton, R. Kannan, S.B. Smith, P.M. Martin, V. Ganapathy, Identification of a novel sodium-coupled oligopeptide transporter (SOPT2) in mouse and human retinal pigment epithelial cells, Invest Ophthalmol Vis Sci, 51 (2010) 413-420.

67. U. Warskulat, B. Heller-Stilb, E. Oermann, K. Zilles, H. Haas, F. Lang, D. Haussinger, Phenotype of the taurine transporter knockout mouse, Methods Enzymol, 428 (2007) 439-458.

68. M.T. Perona, S. Waters, F.S. Hall, I. Sora, K.P. Lesch, D.L. Murphy, M. Caron, G.R. Uhl, Animal models of depression in dopamine, serotonin, and norepinephrine transporter knockout mice: prominent effects of dopamine transporter deletions, Behav Pharmacol, 19 (2008) 566-574.

69. R.A. van Waterschoot, J.S. Lagas, E. Wagenaar, H. Rosing, J.H. Beijnen, A.H. Schinkel, Individual and combined roles of CYP3A, P-glycoprotein (MDR1/ABCB1) and MRP2 (ABCC2) in the pharmacokinetics of docetaxel, Int J Cancer, 127 (2010) 2959-2964.

70. S. Marchetti, N.A. de Vries, T. Buckle, M.J. Bolijn, M.A. van Eijndhoven, J.H. Beijnen, R. Mazzanti, O. van Tellingen, J.H. Schellens, Effect of the ATP-binding cassette drug transporters ABCB1, $\mathrm{ABCG} 2$, and $\mathrm{ABCC} 2$ on erlotinib hydrochloride (Tarceva) disposition in in vitro and in vivo pharmacokinetic studies employing Bcrp1-//Mdr1a/1b-/- (triple-knockout) and wild-type mice, Mol Cancer Ther, 7 (2008) 2280-2287.

71. R.A. van Waterschoot, R. ter Heine, E. Wagenaar, C.M. van der Kruijssen, R.W. Rooswinkel, A.D. Huitema, J.H. Beijnen, A.H. Schinkel, Effects of cytochrome P450 3A (CYP3A) and the drug transporters P-glycoprotein (MDR1/ABCB1) and MRP2 (ABCC2) on the pharmacokinetics of lopinavir, British journal of pharmacology, 160 (2010) 1224-1233.

72. S. Duvvuri, M.D. Gandhi, A.K. Mitra, Effect of Pglycoprotein on the ocular disposition of a model substrate, quinidine, Curr Eye Res, 27 (2003) 345353.

73. S. Dey, S. Gunda, A.K. Mitra, Pharmacokinetics of erythromycin in rabbit corneas after single-dose infusion: role of P-glycoprotein as a barrier to in vivo ocular drug absorption, The Journal of pharmacology and experimental therapeutics, 311 (2004) 246-255.

74. K. Hippalgaonkar, R. Srirangam, B. Avula, I.A. Khan, S. Majumdar, Interaction between topically and systemically coadministered P-glycoprotein substrates/inhibitors: effect on vitreal kinetics, Drug metabolism and disposition: the biological fate of chemicals, 38 (2010) 1790-1797.

75. S. Majumdar, K. Hippalgaonkar, R. Srirangam, Vitreal kinetics of quinidine in rabbits in the presence of topically coadministered Pglycoprotein substrates/modulators, Drug metabolism and disposition: the biological fate of 
chemicals, 37 (2009) 1718-1725.

76. V. Kansara, A.K. Mitra, Evaluation of an ex vivo model implication for carrier-mediated retinal drug delivery, Curr Eye Res, 31 (2006) 415-426.

77. E.B. Mechetner, I.B. Roninson, Efficient inhibition of P-glycoprotein-mediated multidrug resistance with a monoclonal antibody, Proc Natl Acad Sci U S A, 89 (1992) 5824-5828.

78. C.H. Kim, K.J. Park, J.R. Park, Y. Kanai, H. Endou, J.C. Park, K. Kim do, The RNA interference of amino acid transporter LAT1 inhibits the growth of KB human oral cancer cells, Anticancer Res, 26 (2006) 2943-2948.

79. Z. Duan, K.A. Brakora, M.V. Seiden, Inhibition of ABCB1 (MDR1) and ABCB4 (MDR3) expression by small interfering RNA and reversal of paclitaxel resistance in human ovarian cancer cells, Mol Cancer Ther, 3 (2004) 833-838.

80. J.J. Yang, K.J. Kim, V.H. Lee, Role of Pglycoprotein in restricting propranolol transport in cultured rabbit conjunctival epithelial cell layers, Pharmaceutical research, 17 (2000) 533-538.

81. J.J. Yang, D.K. Ann, R. Kannan, V.H. Lee, Multidrug resistance protein 1 (MRP1) in rabbit conjunctival epithelial cells: its effect on drug efflux and its regulation by adenoviral infection, Pharmaceutical research, 24 (2007) 1490-1500.

82. S. Hariharan, M. Minocha, G.P. Mishra, D. Pal, R. Krishna, A.K. Mitra, Interaction of ocular hypotensive agents (PGF2 alpha analogsbimatoprost, latanoprost, and travoprost) with MDR efflux pumps on the rabbit cornea, J Ocul Pharmacol Ther, 25 (2009) 487-498.

83. B.V. Zlokovic, J.B. Mackic, J.G. McComb, R. Kannan, M.H. Weiss, An in situ perfused guineapig eye model for blood-ocular transport studies: application to amino acids, Exp Eye Res, 54 (1992) 471-477.

84. R. Kannan, A. Stolz, Q. Ji, P.D. Prasad, V. Ganapathy, Vitamin C transport in human lens epithelial cells: evidence for the presence of SVCT2, Exp Eye Res, 73 (2001) 159-165.

85. L. Sun, Dipeptide Transport Mechanism in the Pigmented Rabbit Conjunctiva, University of Southern California, 1996.

86. S.K. Basu, I.S. Haworth, M.B. Bolger, V.H. Lee, Proton-driven dipeptide uptake in primary cultured rabbit conjunctival epithelial cells, Invest Ophthalmol Vis Sci, 39 (1998) 2365-2373.

87. M.E. Kraft, H. Glaeser, K. Mandery, J. Konig, D. Auge, M.F. Fromm, U. Schlotzer-Schrehardt, U. Welge-Lussen, F.E. Kruse, O. Zolk, The prostaglandin transporter OATP2A1 is expressed in human ocular tissues and transports the antiglaucoma prostanoid latanoprost, Invest Ophthalmol Vis Sci, 51 (2010) 2504-2511.
88. S. Hariharan, S. Gunda, G.P. Mishra, D. Pal, A.K. Mitra, Enhanced corneal absorption of erythromycin by modulating P-glycoprotein and MRP mediated efflux with corticosteroids, Pharmaceutical research, 26 (2009) 1270-1282.

89. P.K. Karla, D. Pal, T. Quinn, A.K. Mitra, Molecular evidence and functional expression of a novel drug efflux pump (ABCC2) in human corneal epithelium and rabbit cornea and its role in ocular drug efflux, International journal of pharmaceutics, 336 (2007) 12-21.

90. K.S. Vellonen, E. Mannermaa, H. Turner, M. Hakli, J.M. Wolosin, T. Tervo, P. Honkakoski, A. Urtti, Effluxing $\mathrm{ABC}$ transporters in human corneal epithelium, Journal of pharmaceutical sciences, 99 (2010) 1087-1098.

91. H. Zhang, C.W. Wong, P.F. Coville, S. Wanwimolruk, Effect of the grapefruit flavonoid naringin on pharmacokinetics of quinine in rats, Drug Metabol Drug Interact, 17 (2000) 351-363.

92. K.S. Vellonen, M. Hakli, N. Merezhinskaya, T. Tervo, P. Honkakoski, A. Urtti, Monocarboxylate transport in human corneal epithelium and cell lines, Eur J Pharm Sci, 39 (2010) 241-247.

93. S.I. Harik, R.N. Kalaria, P.M. Whitney, L. Andersson, P. Lundahl, S.R. Ledbetter, G. Perry, Glucose transporters are abundant in cells with "occluding" junctions at the blood-eye barriers, Proc Natl Acad Sci U S A, 87 (1990) 4261-4264.

94. E.F. Williams, T.C. Chu, R.R. Socci, L.G. Brown, C.E. Walker, E.L. Manor, Comparison of nucleoside transport binding sites in rabbit irisciliary body and cultured rabbit nonpigmented ciliary epithelial cells, J Ocul Pharmacol Ther, 12 (1996) 461-469.

95. R. Merriman-Smith, P. Donaldson, J. Kistler, Differential expression of facilitative glucose transporters GLUT1 and GLUT3 in the lens, Invest Ophthalmol Vis Sci, 40 (1999) 3224-3230.

96. R.E. Reeves, P.R. Cammarata, Osmoregulatory alterations in myo-inositol uptake by bovine lens epithelial cells. Part 5. Mechanism of the myoinositol efflux pathway, Invest Ophthalmol Vis Sci, 37 (1996) 619-629.

97. B.G. Kennedy, N.J. Mangini, P-glycoprotein expression in human retinal pigment epithelium, Mol Vis, 8 (2002) 422-430.

98. P.A. Constable, J.G. Lawrenson, D.E. Dolman, G.B. Arden, N.J. Abbott, P-Glycoprotein expression in human retinal pigment epithelium cell lines, Exp Eye Res, 83 (2006) 24-30.

99. J.A. Holash, P.A. Stewart, The relationship of astrocyte-like cells to the vessels that contribute to the blood-ocular barriers, Brain research, 629 (1993) 218-224.

100. J.V. Aukunuru, G. Sunkara, N. Bandi, W.B. 
Thoreson, U.B. Kompella, Expression of multidrug resistance-associated protein (MRP) in human retinal pigment epithelial cells and its interaction with BAPSG, a novel aldose reductase inhibitor, Pharmaceutical research, 18 (2001) 565-572.

101. H. Steuer, A. Jaworski, B. Elger, M. Kaussmann, J. Keldenich, H. Schneider, D. Stoll, B. Schlosshauer, Functional characterization and comparison of the outer blood-retina barrier and the blood-brain barrier, Invest Ophthalmol Vis Sci, 46 (2005) 1047-1053.

102. Y. Dun, B. Mysona, S. Itagaki, A. MartinStuddard, V. Ganapathy, S.B. Smith, Functional and molecular analysis of D-serine transport in retinal Muller cells, Exp Eye Res, 84 (2007) 191199.

103. U.V. Berger, M.A. Hediger, Distribution of peptide transporter PEPT2 mRNA in the rat nervous system, Anat Embryol (Berl), 199 (1999) 439-449.

104. S. Macha, A.K. Mitra, Ocular pharmacokinetics of cephalosporins using microdialysis, J Ocul Pharmacol Ther, 17 (2001) 485-498.

105. S.M. Ocheltree, R.F. Keep, H. Shen, D. Yang, B.A. Hughes, D.E. Smith, Preliminary investigation into the expression of proton-coupled oligopeptide transporters in neural retina and retinal pigment epithelium (RPE): lack of functional activity in RPE plasma membranes, Pharmaceutical research, 20 (2003) 1364-1372.

106. H. Atluri, B.S. Anand, J. Patel, A.K. Mitra, Mechanism of a model dipeptide transport across blood-ocular barriers following systemic administration, Exp Eye Res, 78 (2004) 815-822.

107. S. Duvvuri, S. Majumdar, A.K. Mitra, Drug delivery to the retina: challenges and opportunities, Expert Opin Biol Ther, 3 (2003) 45-56.

108. B.S. Winkler, Glycolytic and oxidative metabolism in relation to retinal function, J Gen Physiol, 77 (1981) 667-692.

109. S. Hamann, Molecular mechanisms of water transport in the eye, Int Rev Cytol, 215 (2002) 395431.

110. M.F. Marmor, Mechanisms of fluid accumulation in retinal edema, Doc Ophthalmol, 97 (1999) 239249.

111. G.J. Mantych, G.S. Hageman, S.U. Devaskar, Characterization of glucose transporter isoforms in the adult and developing human eye, Endocrinology, 133 (1993) 600-607.

112. D.V. Pow, Amino acids and their transporters in the retina, Neurochem Int, 38 (2001) 463-484.

113. A.K. Kumagai, B.J. Glasgow, W.M. Pardridge, GLUT1 glucose transporter expression in the diabetic and nondiabetic human eye, Invest Ophthalmol Vis Sci, 35 (1994) 2887-2894.

114. K. Hosoya, T. Kondo, M. Tomi, H. Takanaga, S.
Ohtsuki, T. Terasaki, MCT1-mediated transport of L-lactic acid at the inner blood-retinal barrier: a possible route for delivery of monocarboxylic acid drugs to the retina, Pharmaceutical research, 18 (2001) 1669-1676.

115. Y. Horibe, K. Hosoya, K.J. Kim, V.H. Lee, Carriermediated transport of monocarboxylate drugs in the pigmented rabbit conjunctiva, Invest Ophthalmol Vis Sci, 39 (1998) 1436-1443.

116. H. Yoon, A. Fanelli, E.F. Grollman, N.J. Philp, Identification of a unique monocarboxylate transporter (MCT3) in retinal pigment epithelium, Biochem Biophys Res Commun, 234 (1997) 90-94.

117. V. Kansara, D. Paturi, S. Luo, R. Gaudana, A.K. Mitra, Folic acid transport via high affinity carriermediated system in human retinoblastoma cells, International journal of pharmaceutics, 355 (2008) 210-219.

118. V. Kansara, S. Luo, B. Balasubrahmanyam, D. Pal, A.K. Mitra, Biotin uptake and cellular translocation in human derived retinoblastoma cell line (Y-79): a role of hSMVT system, International journal of pharmaceutics, 312 (2006) 43-52.

119. V. Kansara, D. Pal, R. Jain, A.K. Mitra, Identification and functional characterization of riboflavin transporter in human-derived retinoblastoma cell line (Y-79): mechanisms of cellular uptake and translocation, J Ocul Pharmacol Ther, 21 (2005) 275-287.

120. A. Bill, P. Tornquist, A. Alm, Permeability of the intraocular blood vessels, Trans Ophthalmol Soc U K, 100 (1980) 332-336.

121. T. Zhang, C.D. Xiang, D. Gale, S. Carreiro, E.Y. $\mathrm{Wu}$, E.Y. Zhang, Drug transporter and cytochrome P450 mRNA expression in human ocular barriers: implications for ocular drug disposition, Drug metabolism and disposition: the biological fate of chemicals, 36 (2008) 1300-1307.

122. K. Kawazu, K. Yamada, M. Nakamura, A. Ota, Characterization of cyclosporin A transport in cultured rabbit corneal epithelial cells: Pglycoprotein transport activity and binding to cyclophilin, Invest Ophthalmol Vis Sci, 40 (1999) 1738-1744.

123. S. Dey, J. Patel, B.S. Anand, B. JainVakkalagadda, P. Kaliki, D. Pal, V. Ganapathy, A.K. Mitra, Molecular evidence and functional expression of P-glycoprotein (MDR1) in human and rabbit cornea and corneal epithelial cell lines, Invest Ophthalmol Vis Sci, 44 (2003) 2909-2918.

124. P. Saha, J.J. Yang, V.H. Lee, Existence of a pglycoprotein drug efflux pump in cultured rabbit conjunctival epithelial cells, Invest Ophthalmol Vis Sci, 39 (1998) 1221-1226.

125. P.K. Karla, D. Pal, A.K. Mitra, Molecular evidence and functional expression of multidrug resistance 
associated protein (MRP) in rabbit corneal epithelial cells, Exp Eye Res, 84 (2007) 53-60.

126. B. Jain-Vakkalagadda, D. Pal, S. Gunda, Y. Nashed, V. Ganapathy, A.K. Mitra, Identification of a $\mathrm{Na}+$-dependent cationic and neutral amino acid transporter, $\mathrm{B}(0,+)$, in human and rabbit cornea, Mol Pharm, 1 (2004) 338-346.

127. K. Hosoya, Y. Horibe, K.J. Kim, V.H. Lee, Na(+)dependent L-arginine transport in the pigmented rabbit conjunctiva, Exp Eye Res, 65 (1997) 547553.

128. T. Nakauchi, A. Ando, M. Ueda-Yamada, Y. Yamazaki, M. Uyama, M. Matsumura, S. Ito, Prevention of ornithine cytotoxicity by nonpolar side chain amino acids in retinal pigment epithelial cells, Invest Ophthalmol Vis Sci, 44 (2003) 50235028 .

129. M.D. Gandhi, D. Pal, A.K. Mitra, Identification and functional characterization of a $\mathrm{Na}(+)-$ independent large neutral amino acid transporter (LAT2) on ARPE-19 cells, International journal of pharmaceutics, 275 (2004) 189-200.

130. S.A. Adibi, Renal assimilation of oligopeptides: physiological mechanisms and metabolic importance, Am J Physiol, 272 (1997) E723-736.

131. C.D. Xiang, M. Batugo, D.C. Gale, T. Zhang, J. Ye, C. Li, S. Zhou, E.Y. Wu, E.Y. Zhang, Characterization of human corneal epithelial cell model as a surrogate for corneal permeability assessment: metabolism and transport, Drug metabolism and disposition: the biological fate of chemicals, 37 (2009) 992-998.

132. R.S. Talluri, S. Katragadda, D. Pal, A.K. Mitra, Mechanism of L-ascorbic acid uptake by rabbit corneal epithelial cells: evidence for the involvement of sodium-dependent vitamin $\mathrm{C}$ transporter 2, Curr Eye Res, 31 (2006) 481-489.

133. K.G. Janoria, S. Hariharan, D. Paturi, D. Pal, A.K. Mitra, Biotin uptake by rabbit corneal epithelial cells: role of sodium-dependent multivitamin transporter (SMVT), Curr Eye Res, 31 (2006) 797809.

134. K. Hosoya, K. Fujita, M. Tachikawa, Involvement of reduced folate carrier 1 in the inner blood-retinal barrier transport of methyltetrahydrofolate, Drug Metab Pharmacokinet, 23 (2008) 285-292.

135. I.P. Kaur, M. Kanwar, Ocular preparations: the formulation approach, Drug Dev Ind Pharm, 28 (2002) 473-493.

136. E. Ghelardi, A. Tavanti, F. Celandroni, A. Lupetti, C. Blandizzi, E. Boldrini, M. Campa, S. Senesi, Effect of a novel mucoadhesive polysaccharide obtained from tamarind seeds on the intraocular penetration of gentamicin and ofloxacin in rabbits, J Antimicrob Chemother, 46 (2000) 831-834.

137. E. Ghelardi, A. Tavanti, P. Davini, F. Celandroni,
S. Salvetti, E. Parisio, E. Boldrini, S. Senesi, M. Campa, A mucoadhesive polymer extracted from tamarind seed improves the intraocular penetration and efficacy of rufloxacin in topical treatment of experimental bacterial keratitis, Antimicrobial agents and chemotherapy, 48 (2004) 3396-3401.

138. A. Czajkowska-Kosnik, M. Sznitowska, Solubility of ocular therapeutic agents in self-emulsifying oils. I. Self-emulsifying oils for ocular drug delivery: solubility of indomethacin, aciclovir and hydrocortisone, Acta Pol Pharm, 66 (2009) 709713.

139. M.F. Saettone, D. Monti, M.T. Torracca, P. Chetoni, Mucoadhesive ophthalmic vehicles: evaluation of polymeric low-viscosity formulations, J Ocul Pharmacol, 10 (1994) 83-92.

140. F. Faraldi, V. Papa, D. Santoro, D. Rasa, A.L. Mazza, M.M. Rabbione, S. Russo, A new eye gel containing sodium hyaluronate and xanthan gum for the management of post-traumatic corneal abrasions, Clin Ophthalmol, 6 (2012) 727-731.

141. P.K. Deshmukh, S.G. Gattani, In vitro and in vivo consideration of novel environmentally responsive ophthalmic drug delivery system, Pharm Dev Technol, (2011).

142. C. Baudouin, B. Cochener, P.J. Pisella, B. Girard, P. Pouliquen, H. Cooper, C. Creuzot-Garcher, Randomized, phase III study comparing osmoprotective carboxymethylcellulose with sodium hyaluronate in dry eye disease, Eur $\mathrm{J}$ Ophthalmol, 22 (2012) 751-761.

143. J.H. Lee, H.S. Ahn, E.K. Kim, T.I. Kim, Efficacy of sodium hyaluronate and carboxymethylcellulose in treating mild to moderate dry eye disease, Cornea, 30 (2011) 175-179.

144. M.F. Saettone, P. Chetoni, R. Cerbai, G. Mazzanti, L. Braghiroli, Evaluation of ocular permeation enhancers: In vitro effects on corneal transport of four $\beta$-blockers, and in vitro/in vivo toxic activity, International journal of pharmaceutics, 142 (1996) 103-113.

145. O. Camber, P. Edman, Influence of some preservatives on the corneal permeability of pilocarpine and dexamethasone, in vitro, International journal of pharmaceutics, 39 (1987) 229-234.

146. I.P. Kaur, M. Singh, M. Kanwar, Formulation and evaluation of ophthalmic preparations of acetazolamide, International journal of pharmaceutics, 199 (2000) 119-127.

147. L. Yu, A. Bridgers, J. Polli, A. Vickers, S. Long, A. Roy, R. Winnike, M. Coffin, Vitamin E-TPGS increases absorption flux of an HIV protease inhibitor by enhancing its solubility and permeability, Pharmaceutical research, 16 (1999) 1812-1817. 
148. M.V. Varma, R. Panchagnula, Enhanced oral paclitaxel absorption with vitamin E-TPGS: effect on solubility and permeability in vitro, in situ and in vivo, Eur J Pharm Sci, 25 (2005) 445-453.

149. J.W. Valle, A. Armstrong, C. Newman, V. Alakhov, G. Pietrzynski, J. Brewer, S. Campbell, P. Corrie, E.K. Rowinsky, M. Ranson, A phase 2 study of SP1049C, doxorubicin in P-glycoproteintargeting pluronics, in patients with advanced adenocarcinoma of the esophagus and gastroesophageal junction, Investigational new drugs, 29 (2011) 1029-1037.

150. D.Y. Alakhova, N.Y. Rapoport, E.V. Batrakova, A.A. Timoshin, S. Li, D. Nicholls, V.Y. Alakhov, A.V. Kabanov, Differential metabolic responses to pluronic in MDR and non-MDR cells: a novel pathway for chemosensitization of drug resistant cancers, J Control Release, 142 (2010) 89-100.

151. L. Ma, Y. Wei, Y. Zhou, X. Ma, X. Wu, Effects of Pluronic F68 and Labrasol on the intestinal absorption and pharmacokinetics of rifampicin in rats, Archives of pharmacal research, 34 (2011) 1939-1943.

152. Y. Lin, Q. Shen, H. Katsumi, N. Okada, T. Fujita, X. Jiang, A. Yamamoto, Effects of Labrasol and other pharmaceutical excipients on the intestinal transport and absorption of rhodamine123, a Pglycoprotein substrate, in rats, Biol Pharm Bull, 30 (2007) 1301-1307.

153. H. Arima, K. Yunomae, F. Hirayama, K. Uekama, Contribution of P-glycoprotein to the enhancing effects of dimethyl-beta-cyclodextrin on oral bioavailability of tacrolimus, The Journal of pharmacology and experimental therapeutics, 297 (2001) 547-555.

154. E.D. Hugger, K.L. Audus, R.T. Borchardt, Effects of poly(ethylene glycol) on efflux transporter activity in Caco-2 cell monolayers, Journal of pharmaceutical sciences, 91 (2002) 1980-1990.

155. B.D. Rege, J.P. Kao, J.E. Polli, Effects of nonionic surfactants on membrane transporters in Caco-2 cell monolayers, Eur J Pharm Sci, 16 (2002) 237246.

156. E.D. Hugger, B.L. Novak, P.S. Burton, K.L. Audus, R.T. Borchardt, A comparison of commonly used polyethoxylated pharmaceutical excipients on their ability to inhibit P-glycoprotein activity in vitro, Journal of pharmaceutical sciences, 91 (2002) 1991-2002.

157. B.S. Anand, A.K. Mitra, Mechanism of corneal permeation of L-valyl ester of acyclovir: targeting the oligopeptide transporter on the rabbit cornea, Pharmaceutical research, 19 (2002) 1194-1202.

158. Y.E. Nashed, A.K. Mitra, Synthesis and characterization of novel dipeptide ester prodrugs of acyclovir, Spectrochim Acta A Mol Biomol
Spectrosc, 59 (2003) 2033-2039.

159. B. Anand, Y. Nashed, A. Mitra, Novel dipeptide prodrugs of acyclovir for ocular herpes infections: Bioreversion, antiviral activity and transport across rabbit cornea, Curr Eye Res, 26 (2003) 151-163.

160. D.R. Mudra, K.E. Desino, P.V. Desai, In silico, in vitro and in situ models to assess interplay between CYP3A and P-gp, Current drug metabolism, 12 (2011) 750-773.

161. A.S. Darwich, S. Neuhoff, M. Jamei, A. RostamiHodjegan, Interplay of metabolism and transport in determining oral drug absorption and gut wall metabolism: a simulation assessment using the "Advanced Dissolution, Absorption, Metabolism (ADAM)" model, Current drug metabolism, 11 (2010) 716-729.

162. R.A. van Waterschoot, A.H. Schinkel, A critical analysis of the interplay between cytochrome P450 $3 \mathrm{~A}$ and P-glycoprotein: recent insights from knockout and transgenic mice, Pharmacol Rev, 63 (2011) 390-410.

163. K.T. Kivisto, M. Niemi, M.F. Fromm, Functional interaction of intestinal CYP3A4 and Pglycoprotein, Fundamental \& clinical pharmacology, 18 (2004) 621-626.

164. S. Wang, Interplay between efflux transporters and metabolic enzymes, in: M. Hu, X. Li (Eds.) Oral Bioavailability: Basic Principles, Advanced Concepts, and Applications, John Wiley \& Sons, Inc., Hoboken, New Jersey, 2011, pp. 401-412.

165. J.A. Yanez, D.R. Brocks, M.L. Forrest, N.M. Davies, Pharmacokinetic Behaviors of Orally Administered Drugs, in: M. Hu, X. Li (Eds.) Oral Bioavailability: Basic Principles, Advanced Concepts, and Applications, John Wiley \& Sons, Inc., Hoboken, New Jersey, 2011, pp. 183-220.

166. B. Bretschneider, M. Brandsch, R. Neubert, Intestinal transport of beta-lactam antibiotics: analysis of the affinity at the $\mathrm{H}+$ /peptide symporter (PEPT1), the uptake into Caco-2 cell monolayers and the transepithelial flux, Pharmaceutical research, 16 (1999) 55-61.

167. H. Yabuuchi, I. Tamai, K. Morita, T. Kouda, K. Miyamoto, E. Takeda, A. Tsuji, Hepatic sinusoidal membrane transport of anionic drugs mediated by anion transporter Npt1, The Journal of pharmacology and experimental therapeutics, 286 (1998) 1391-1396.

168. S. Jariyawat, T. Sekine, M. Takeda, N. Apiwattanakul, Y. Kanai, S. Sophasan, H. Endou, The interaction and transport of beta-lactam antibiotics with the cloned rat renal organic anion transporter 1, The Journal of pharmacology and experimental therapeutics, 290 (1999) 672-677.

169. T. Itoh, H. Nakaura, S. Koyano, Y. Tsuda, H. Yamada, Stereoselective renal secretion of 
carbenicillin in rabbits: role of the organic anion transporter at the renal brush border membrane, Chirality, 10 (1998) 349-357.

170. M. Takeda, E. Babu, S. Narikawa, H. Endou, Interaction of human organic anion transporters with various cephalosporin antibiotics, European journal of pharmacology, 438 (2002) 137-142.

171. S. Khamdang, M. Takeda, E. Babu, R. Noshiro, M.L. Onozato, A. Tojo, A. Enomoto, X.L. Huang, S. Narikawa, N. Anzai, P. Piyachaturawat, H. Endou, Interaction of human and rat organic anion transporter 2 with various cephalosporin antibiotics, European journal of pharmacology, 465 (2003) 1-7.

172. M. Hosoyamada, T. Sekine, Y. Kanai, H. Endou, Molecular cloning and functional expression of a multispecific organic anion transporter from human kidney, Am J Physiol, 276 (1999) F122-128.

173. M. Takeda, S. Khamdang, S. Narikawa, H. Kimura, M. Hosoyamada, S.H. Cha, T. Sekine, H. Endou, Characterization of methotrexate transport and its drug interactions with human organic anion transporters, The Journal of pharmacology and experimental therapeutics, 302 (2002) 666-671.

174. S.H. Cha, T. Sekine, J.I. Fukushima, Y. Kanai, Y. Kobayashi, T. Goya, H. Endou, Identification and characterization of human organic anion transporter 3 expressing predominantly in the kidney, Mol Pharmacol, 59 (2001) 1277-1286.

175. S.H. Cha, T. Sekine, H. Kusuhara, E. Yu, J.Y. Kim, D.K. Kim, Y. Sugiyama, Y. Kanai, H. Endou, Molecular cloning and characterization of multispecific organic anion transporter 4 expressed in the placenta, J Biol Chem, 275 (2000) 45074512.

176. I. Tamai, J. Nezu, H. Uchino, Y. Sai, A. Oku, M. Shimane, A. Tsuji, Molecular identification and characterization of novel members of the human organic anion transporter (OATP) family, Biochem Biophys Res Commun, 273 (2000) 251-260.

177. R.K. Bhardwaj, D. Herrera-Ruiz, P.J. Sinko, O.S. Gudmundsson, G. Knipp, Delineation of human peptide transporter 1 (hPepT1)-mediated uptake and transport of substrates with varying transporter affinities utilizing stably transfected hPepT1/Madin-Darby canine kidney clones and Caco-2 cells, The Journal of pharmacology and experimental therapeutics, 314 (2005) 1093-1100.

178. S. Masuda, K. Ibaramoto, A. Takeuchi, H. Saito, Y. Hashimoto, K.I. Inui, Cloning and functional characterization of a new multispecific organic anion transporter, OAT-K2, in rat kidney, Mol Pharmacol, 55 (1999) 743-752.

179. H. Uchino, I. Tamai, K. Yamashita, Y. Minemoto, Y. Sai, H. Yabuuchi, K. Miyamoto, E. Takeda, A. Tsuji, p-aminohippuric acid transport at renal apical membrane mediated by human inorganic phosphate transporter NPT1, Biochem Biophys Res Commun, 270 (2000) 254-259.

180. Y. Shitara, D. Sugiyama, H. Kusuhara, Y. Kato, T. Abe, P.J. Meier, T. Itoh, Y. Sugiyama, Comparative inhibitory effects of different compounds on rat oatpl (slc21a1)- and Oatp2 (Slc21a5)-mediated transport, Pharmaceutical research, 19 (2002) 147-153.

181. K. Letschert, H. Faulstich, D. Keller, D. Keppler, Molecular characterization and inhibition of amanitin uptake into human hepatocytes, Toxicol Sci, 91 (2006) 140-149.

182. J.M. Michot, F. Van Bambeke, M.P. MingeotLeclercq, P.M. Tulkens, Active efflux of ciprofloxacin from J774 macrophages through an MRP-like transporter, Antimicrobial agents and chemotherapy, 48 (2004) 2673-2682.

183. J.M. Michot, C. Seral, F. Van Bambeke, M.P. Mingeot-Leclercq, P.M. Tulkens, Influence of efflux transporters on the accumulation and efflux of four quinolones (ciprofloxacin, levofloxacin, garenoxacin, and moxifloxacin) in $\mathrm{J} 774$ macrophages, Antimicrobial agents and chemotherapy, 49 (2005) 2429-2437.

184. J.M. Michot, M.F. Heremans, N.E. Caceres, M.P. Mingeot-Leclercq, P.M. Tulkens, F. Van Bambeke, Cellular accumulation and activity of quinolones in ciprofloxacin-resistant J774 macrophages, Antimicrobial agents and chemotherapy, 50 (2006) 1689-1695.

185. G. Merino, A.I. Alvarez, M.M. Pulido, A.J. Molina, A.H. Schinkel, J.G. Prieto, Breast cancer resistance protein (BCRP/ABCG2) transports fluoroquinolone antibiotics and affects their oral availability, pharmacokinetics, and milk secretion, Drug metabolism and disposition: the biological fate of chemicals, 34 (2006) 690-695.

186. S. Zakelj, K. Sturm, A. Kristl, Ciprofloxacin permeability and its active secretion through rat small intestine in vitro, International journal of pharmaceutics, 313 (2006) 175-180.

187. T. Ito, I. Yano, K. Tanaka, K.I. Inui, Transport of quinolone antibacterial drugs by human Pglycoprotein expressed in a kidney epithelial cell line, LLC-PK1, The Journal of pharmacology and experimental therapeutics, 282 (1997) 955-960.

188. Y. Urakami, M. Akazawa, H. Saito, M. Okuda, K. Inui, cDNA cloning, functional characterization, and tissue distribution of an alternatively spliced variant of organic cation transporter hOCT2 predominantly expressed in the human kidney, $\mathrm{J}$ Am Soc Nephrol, 13 (2002) 1703-1710.

189. K. Terashi, M. Oka, H. Soda, M. Fukuda, S. Kawabata, K. Nakatomi, K. Shiozawa, T. Nakamura, K. Tsukamoto, Y. Noguchi, M. 
Suenaga, C. Tei, S. Kohno, Interactions of ofloxacin and erythromycin with the multidrug resistance protein (MRP) in MRP-overexpressing human leukemia cells, Antimicrobial agents and chemotherapy, 44 (2000) 1697-1700.

190. L. Rabbaa, S. Dautrey, N. Colas-Linhart, C. Carbon, R. Farinotti, Intestinal elimination of ofloxacin enantiomers in the rat: evidence of a carrier-mediated process, Antimicrobial agents and chemotherapy, 40 (1996) 2126-2130.

191. T. Okano, H. Maegawa, K. Inui, R. Hori, Interaction of ofloxacin with organic cation transport system in rat renal brush-border membranes, The Journal of pharmacology and experimental therapeutics, 255 (1990) 1033-1037.

192. M. Takano, R. Hasegawa, T. Fukuda, R. Yumoto, J. Nagai, T. Murakami, Interaction with Pglycoprotein and transport of erythromycin, midazolam and ketoconazole in Caco-2 cells, European journal of pharmacology, 358 (1998) 289-294.

193. Y. Kobayashi, R. Sakai, N. Ohshiro, M. Ohbayashi, N. Kohyama, T. Yamamoto, Possible involvement of organic anion transporter 2 on the interaction of theophylline with erythromycin in the human liver, Drug metabolism and disposition: the biological fate of chemicals, 33 (2005) 619-622.

194. M. Cvetkovic, B. Leake, M.F. Fromm, G.R. Wilkinson, R.B. Kim, OATP and P-glycoprotein transporters mediate the cellular uptake and excretion of fexofenadine, Drug metabolism and disposition: the biological fate of chemicals, 27 (1999) 866-871.

195. J.L. Lam, H. Okochi, Y. Huang, L.Z. Benet, In vitro and in vivo correlation of hepatic transporter effects on erythromycin metabolism: characterizing the importance of transporter-enzyme interplay, Drug metabolism and disposition: the biological fate of chemicals, 34 (2006) 1336-1344.

196. E. Babu, M. Takeda, S. Narikawa, Y. Kobayashi, T. Yamamoto, S.H. Cha, T. Sekine, D. Sakthisekaran, H. Endou, Human organic anion transporters mediate the transport of tetracycline, Jpn J Pharmacol, 88 (2002) 69-76.

197. K.A. Bode, M.G. Donner, I. Leier, D. Keppler, Inhibition of transport across the hepatocyte canalicular membrane by the antibiotic fusidate, Biochemical pharmacology, 64 (2002) 151-158.

198. A. Klokouzas, M.A. Barrand, S.B. Hladky, Effects of clotrimazole on transport mediated by multidrug resistance associated protein 1 (MRP1) in human erythrocytes and tumour cells, Eur J Biochem, 268 (2001) 6569-6577.

199. T. Sakaeda, K. Iwaki, M. Kakumoto, M. Nishikawa, T. Niwa, J.S. Jin, T. Nakamura, K. Nishiguchi, N. Okamura, K. Okumura, Effect of micafungin on cytochrome P450 3A4 and multidrug resistance protein 1 activities, and its comparison with azole antifungal drugs, J Pharm Pharmacol, 57 (2005) 759-764.

200. S. Wada, M. Tsuda, T. Sekine, S.H. Cha, M. Kimura, Y. Kanai, H. Endou, Rat multispecific organic anion transporter 1 (rOAT1) transports zidovudine, acyclovir, and other antiviral nucleoside analogs, The Journal of pharmacology and experimental therapeutics, 294 (2000) 844-849.

201. M. Takeda, S. Khamdang, S. Narikawa, H. Kimura, Y. Kobayashi, T. Yamamoto, S.H. Cha, T. Sekine, H. Endou, Human organic anion transporters and human organic cation transporters mediate renal antiviral transport, The Journal of pharmacology and experimental therapeutics, 300 (2002) 918-924.

202. T. Cihlar, D.C. Lin, J.B. Pritchard, M.D. Fuller, D.B. Mendel, D.H. Sweet, The antiviral nucleotide analogs cidofovir and adefovir are novel substrates for human and rat renal organic anion transporter 1, Mol Pharmacol, 56 (1999) 570-580.

203. E.S. Ho, D.C. Lin, D.B. Mendel, T. Cihlar, Cytotoxicity of antiviral nucleotides adefovir and cidofovir is induced by the expression of human renal organic anion transporter 1, J Am Soc Nephrol, 11 (2000) 383-393.

204. Y. Kido, I. Tamai, M. Okamoto, F. Suzuki, A. Tsuji, Functional clarification of MCT1-mediated transport of monocarboxylic acids at the bloodbrain barrier using in vitro cultured cells and in vivo BUI studies, Pharmaceutical research, 17 (2000) 55-62.

205. M. Adachi, J. Sampath, L.B. Lan, D. Sun, P. Hargrove, R. Flatley, A. Tatum, M.Z. Edwards, M. Wezeman, L. Matherly, R. Drake, J. Schuetz, Expression of MRP4 confers resistance to ganciclovir and compromises bystander cell killing, J Biol Chem, 277 (2002) 38998-39004.

206. S. Majumdar, S. Gunda, A. Mitra, Functional expression of a sodium dependent nucleoside transporter on rabbit cornea: Role in corneal permeation of acyclovir and idoxuridine, Curr Eye Res, 26 (2003) 175-183.

207. X. Fang, F.E. Parkinson, D.A. Mowles, J.D. Young, C.E. Cass, Functional characterization of a recombinant sodium-dependent nucleoside transporter with selectivity for pyrimidine nucleosides (cNT1rat) by transient expression in cultured mammalian cells, Biochem J, 317 ( Pt 2) (1996) 457-465.

208. P.V. Balimane, I. Tamai, A. Guo, T. Nakanishi, H. Kitada, F.H. Leibach, A. Tsuji, P.J. Sinko, Direct evidence for peptide transporter (PepT1)-mediated uptake of a nonpeptide prodrug, valacyclovir, Biochem Biophys Res Commun, 250 (1998) 246251. 
209. T. Hatanaka, M. Haramura, Y.J. Fei, S. Miyauchi, C.C. Bridges, P.S. Ganapathy, S.B. Smith, V. Ganapathy, M.E. Ganapathy, Transport of amino acid-based prodrugs by the $\mathrm{Na}+$ - and $\mathrm{Cl}(-)$-coupled amino acid transporter ATB0,+ and expression of the transporter in tissues amenable for drug delivery, The Journal of pharmacology and experimental therapeutics, 308 (2004) 1138-1147.

210. M.E. Ganapathy, W. Huang, H. Wang, V. Ganapathy, F.H. Leibach, Valacyclovir: a substrate for the intestinal and renal peptide transporters PEPT1 and PEPT2, Biochem Biophys Res Commun, 246 (1998) 470-475.

211. X. Wang, T. Furukawa, T. Nitanda, M. Okamoto, Y. Sugimoto, S. Akiyama, M. Baba, Breast cancer resistance protein (BCRP/ABCG2) induces cellular resistance to $\mathrm{HIV}-1$ nucleoside reverse transcriptase inhibitors, Mol Pharmacol, 63 (2003) 65-72.

212. J.D. Schuetz, M.C. Connelly, D. Sun, S.G. Paibir, P.M. Flynn, R.V. Srinivas, A. Kumar, A. Fridland, MRP4: A previously unidentified factor in resistance to nucleoside-based antiviral drugs, Nat Med, 5 (1999) 1048-1051.

213. A. Takeuchi, S. Masuda, H. Saito, T. Abe, K. Inui, Multispecific substrate recognition of kidneyspecific organic anion transporters OAT-K1 and OAT-K2, The Journal of pharmacology and experimental therapeutics, 299 (2001) 261-267.

214. M.W. Ritzel, S.Y. Yao, M.Y. Huang, J.F. Elliott, C.E. Cass, J.D. Young, Molecular cloning and functional expression of cDNAs encoding a human Nat-nucleoside cotransporter (hCNT1), Am J Physiol, 272 (1997) C707-714.

215. N. Morita, H. Kusuhara, T. Sekine, H. Endou, Y. Sugiyama, Functional characterization of rat organic anion transporter 2 in LLC-PK1 cells, The Journal of pharmacology and experimental therapeutics, 298 (2001) 1179-1184.

216. P. Pavek, G. Merino, E. Wagenaar, E. Bolscher, M. Novotna, J.W. Jonker, A.H. Schinkel, Human breast cancer resistance protein: interactions with steroid drugs, hormones, the dietary carcinogen 2amino-1-methyl-6-phenylimidazo(4,5-b)pyridine, and transport of cimetidine, The Journal of pharmacology and experimental therapeutics, 312 (2005) 144-152.

217. H.C. Cooray, S. Shahi, A.P. Cahn, H.W. van Veen, S.B. Hladky, M.A. Barrand, Modulation of pglycoprotein and breast cancer resistance protein by some prescribed corticosteroids, European journal of pharmacology, 531 (2006) 25-33.

218. C.R. Yates, C. Chang, J.D. Kearbey, K. Yasuda, E.G. Schuetz, D.D. Miller, J.T. Dalton, P.W. Swaan, Structural determinants of P-glycoproteinmediated transport of glucocorticoids,
Pharmaceutical research, 20 (2003) 1794-1803.

219. K. Ueda, N. Okamura, M. Hirai, Y. Tanigawara, T. Saeki, N. Kioka, T. Komano, R. Hori, Human Pglycoprotein transports cortisol, aldosterone, and dexamethasone, but not progesterone, J Biol Chem, 267 (1992) 24248-24252.

220. G.A. Kullak-Ublick, T. Fisch, M. Oswald, B. Hagenbuch, P.J. Meier, U. Beuers, G. Paumgartner, Dehydroepiandrosterone sulfate (DHEAS): identification of a carrier protein in human liver and brain, FEBS Lett, 424 (1998) 173-176.

221. X. Bossuyt, M. Muller, B. Hagenbuch, P.J. Meier, Polyspecific drug and steroid clearance by an organic anion transporter of mammalian liver, The Journal of pharmacology and experimental therapeutics, 276 (1996) 891-896.

222. U.S. Rao, R.L. Fine, G.A. Scarborough, Antiestrogens and steroid hormones: substrates of the human P-glycoprotein, Biochemical pharmacology, 48 (1994) 287-292.

223. N. Kanai, R. Lu, Y. Bao, A.W. Wolkoff, V.L. Schuster, Transient expression of oatp organic anion transporter in mammalian cells: identification of candidate substrates, Am J Physiol, 270 (1996) F319-325.

224. S. Khamdang, M. Takeda, R. Noshiro, S. Narikawa, A. Enomoto, N. Anzai, P. Piyachaturawat, H. Endou, Interactions of human organic anion transporters and human organic cation transporters with nonsteroidal antiinflammatory drugs, The Journal of pharmacology and experimental therapeutics, 303 (2002) 534-539.

225. A.S. Mulato, E.S. Ho, T. Cihlar, Nonsteroidal antiinflammatory drugs efficiently reduce the transport and cytotoxicity of adefovir mediated by the human renal organic anion transporter 1, The Journal of pharmacology and experimental therapeutics, 295 (2000) 10-15.

226. S. Pratt, R.L. Shepard, R.A. Kandasamy, P.A. Johnston, W. Perry, 3rd, A.H. Dantzig, The multidrug resistance protein 5 (ABCC5) confers resistance to 5-fluorouracil and transports its monophosphorylated metabolites, Mol Cancer Ther, 4 (2005) 855-863.

227. Y. Guo, E. Kotova, Z.S. Chen, K. Lee, E. HopperBorge, M.G. Belinsky, G.D. Kruh, MRP8, ATPbinding cassette $\mathrm{C} 11$ (ABCC11), is a cyclic nucleotide efflux pump and a resistance factor for fluoropyrimidines 2',3'-dideoxycytidine and 9'-(2'phosphonylmethoxyethyl)adenine, J Biol Chem, 278 (2003) 29509-29514.

228. N. Zhang, R. Kannan, C.T. Okamoto, S.J. Ryan, V.H. Lee, D.R. Hinton, Characterization of brimonidine transport in retinal pigment epithelium, Invest Ophthalmol Vis Sci, 47 (2006) 287-294. 
229. Y.H. Han, D.H. Sweet, D.N. Hu, J.B. Pritchard, Characterization of a novel cationic drug transporter in human retinal pigment epithelial cells, The Journal of pharmacology and experimental therapeutics, 296 (2001) 450-457.

230. T. Terao, E. Hisanaga, Y. Sai, I. Tamai, A. Tsuji, Active secretion of drugs from the small intestinal epithelium in rats by P-glycoprotein functioning as an absorption barrier, J Pharm Pharmacol, 48 (1996) 1083-1089.

231. B. Gao, R.D. Huber, A. Wenzel, S.R. Vavricka, M.G. Ismair, C. Reme, P.J. Meier, Localization of organic anion transporting polypeptides in the rat and human ciliary body epithelium, Exp Eye Res, 80 (2005) 61-72.

232. M. Katoh, M. Nakajima, H. Yamazaki, T. Yokoi, Inhibitory effects of CYP3A4 substrates and their metabolites on P-glycoprotein-mediated transport, Eur J Pharm Sci, 12 (2001) 505-513.

233. Y. Zhang, S.A. Berger, Ketotifen reverses MDR1mediated multidrug resistance in human breast cancer cells in vitro and alleviates cardiotoxicity induced by doxorubicin in vivo, Cancer chemotherapy and pharmacology, 51 (2003) 407414.

234. M. Qadir, K.L. O'Loughlin, S.M. Fricke, N.A. Williamson, W.R. Greco, H. Minderman, M.R. Baer, Cyclosporin A is a broad-spectrum multidrug resistance modulator, Clin Cancer Res, 11 (2005) 2320-2326.

235. M. Yamazaki, B. Li, S.W. Louie, N.T. Pudvah, R. Stocco, W. Wong, M. Abramovitz, A. Demartis, R. Laufer, J.H. Hochman, T. Prueksaritanont, J.H. Lin, Effects of fibrates on human organic aniontransporting polypeptide 1B1-, multidrug resistance protein 2- and P-glycoprotein-mediated transport, Xenobiotica; the fate of foreign compounds in biological systems, 35 (2005) 737-753.

236. T. Fehrenbach, Y. Cui, H. Faulstich, D. Keppler, Characterization of the transport of the bicyclic peptide phalloidin by human hepatic transport proteins, Naunyn Schmiedebergs Arch Pharmacol, 368 (2003) 415-420.

237. Y. Shitara, T. Itoh, H. Sato, A.P. Li, Y. Sugiyama, Inhibition of transporter-mediated hepatic uptake as a mechanism for drug-drug interaction between cerivastatin and cyclosporin $\mathrm{A}$, The Journal of pharmacology and experimental therapeutics, 304 (2003) 610-616.

238. W. Sun, R.R. Wu, P.D. van Poelje, M.D. Erion, Isolation of a family of organic anion transporters from human liver and kidney, Biochem Biophys Res Commun, 283 (2001) 417-422.

239. H. Sun, D.R. Johnson, R.A. Finch, A.C. Sartorelli, D.W. Miller, W.F. Elmquist, Transport of fluorescein in MDCKII-MRP1 transfected cells and mrp1-knockout mice, Biochem Biophys Res Commun, 284 (2001) 863-869.

240. C. Saengkhae, C. Loetchutinat, A. GarnierSuillerot, Kinetic analysis of fluorescein and dihydrofluorescein effluxes in tumour cells expressing the multidrug resistance protein, MRP1, Biochemical pharmacology, 65 (2003) 969-977.

241. D. Sykes, D.H. Sweet, S. Lowes, S.K. Nigam, J.B. Pritchard, D.S. Miller, Organic anion transport in choroid plexus from wild-type and organic anion transporter 3 (Slc22a8)-null mice, Am J Physiol Renal Physiol, 286 (2004) F972-978.

242. Y. Konishi, K. Hagiwara, M. Shimizu, Transepithelial transport of fluorescein in Caco-2 cell monolayers and use of such transport in in vitro evaluation of phenolic acid availability, Bioscience, biotechnology, and biochemistry, 66 (2002) 2449-2457.

243. T. Cihlar, E.S. Ho, Fluorescence-based assay for the interaction of small molecules with the human renal organic anion transporter 1, Anal Biochem, 283 (2000) 49-55.

244. S. Majumdar, T. Hingorani, R. Srirangam, R.S. Gadepalli, J.M. Rimoldi, M.A. Repka, Transcorneal permeation of L- and D-aspartate ester prodrugs of acyclovir: delineation of passive diffusion versus transporter involvement, Pharmaceutical research, 26 (2009) 1261-1269.

245. B.S. Anand, S. Katragadda, Y.E. Nashed, A.K. Mitra, Amino acid prodrugs of acyclovir as possible antiviral agents against ocular HSV-1 infections: interactions with the neutral and cationic amino acid transporter on the corneal epithelium, Curr Eye Res, 29 (2004) 153-166.

246. S. Gunda, S. Hariharan, A.K. Mitra, Corneal absorption and anterior chamber pharmacokinetics of dipeptide monoester prodrugs of ganciclovir (GCV): in vivo comparative evaluation of these prodrugs with Val-GCV and GCV in rabbits, $\mathrm{J}$ Ocul Pharmacol Ther, 22 (2006) 465-476.

247. S. Majumdar, Y.E. Nashed, K. Patel, R. Jain, M. Itahashi, D.M. Neumann, J.M. Hill, A.K. Mitra, Dipeptide monoester ganciclovir prodrugs for treating HSV-1-induced corneal epithelial and stromal keratitis: in vitro and in vivo evaluations, $\mathrm{J}$ Ocul Pharmacol Ther, 21 (2005) 463-474.

248. S. Katragadda, R.S. Talluri, A.K. Mitra, Modulation of P-glycoprotein-mediated efflux by prodrug derivatization: an approach involving peptide transporter-mediated influx across rabbit cornea, J Ocul Pharmacol Ther, 22 (2006) 110-120.

249. V. Kansara, Y. Hao, A.K. Mitra, Dipeptide monoester ganciclovir prodrugs for transscleral drug delivery: targeting the oligopeptide transporter on rabbit retina, J Ocul Pharmacol Ther, 23 (2007) 321-334. 
250. K.G. Janoria, S.H. Boddu, Z. Wang, D.K. Paturi, S. Samanta, D. Pal, A.K. Mitra, Vitreal pharmacokinetics of biotinylated ganciclovir: role of sodium-dependent multivitamin transporter expressed on retina, J Ocul Pharmacol Ther, 25 (2009) 39-49.
251. A. Dalpiaz, R. Filosa, P. de Caprariis, G. Conte, F. Bortolotti, C. Biondi, A. Scatturin, P.D. Prasad, B. Pavan, Molecular mechanism involved in the transport of a prodrug dopamine glycosyl conjugate, International journal of pharmaceutics, 336 (2007) 133-139. 